Article

\title{
Peace with Pirates? Maghrebi Maritime Combat, Diplomacy, and Trade in English Periodical News, 1622-1714
}

\author{
Nat Cutter ${ }^{(\mathbb{D}}$
}

School of Historical and Philosophical Studies, University of Melbourne, Melbourne 3010, Australia; nat@cutters.org

Received: 1 October 2019; Accepted: 18 November 2019; Published: 20 November 2019

\begin{abstract}
Commonly represented in contemporary texts and modern historiographical accounts as a dangerous and alien region, characterised by piracy and barbarism, the history of the early modern Maghreb and the cultural impact it had on British society is one highly limited by indirect sources, cultural, political, and religious biases, and the distorting influence of Orientalist and colonial historiography. Historians have drawn on a wide range of popular media and government-held archival material, each with its own limitations, but one important corpus has been neglected. Drawn from up-to-date and trusted sources and distributed to vast audiences from a wide range of social groups, periodical news publications provide a vast and fruitful body of sources for evaluating popular and elite English viewpoints on Maghrebi piracy. This paper draws upon a corpus of 3385 news items comprising over 360,000 words relating to the Maghreb and its people, drawn from Stuart and Republican English news publications, with a view towards examining the discourse and reality around Maghrebi maritime combat, diplomact and trade in seventeenth- and early eighteenth-century England. To what extent did maritime combat dominate coverage of the Maghreb, over other social, political and military events? Why did news writers use the word 'pirate' so infrequently to describe Maghrebi ships? Was Maghrebi piracy chaotic and unfettered, or did peace treaties and consular presence lead to stable trade relations? Were Maghrebi economies seen to be fundamentally built on naval predation, or was real benefit available from peaceful engagement with the Maghrebi states? Examining these and other questions from English news coverage, this paper argues that the material in English periodical news is generally consistent with what we know of the military, diplomatic and economic conditions of the time, surprisingly neutral in tone with a possible emphasis on positive stories when dealing with British-Maghrebi relations, and increasingly after the Restoration played a significant role in influencing British popular discourse.
\end{abstract}

Keywords: England; Algeria; Tunisia; Libya; Morocco; newspaper; Barbary; discourse; orientalism; Mediterranean

\section{Introduction}

In 1622, it was reported in a letter from Algiers 'that the Ambassador of the States of the Low Countryes Doctor Pinacker, had so well sped himself in his ambassage, that he had obtained an agreement betwixt those of Algier, and the united Provinces' (Brief Abstracts out of Diverse Letters of Trust, 18 October 1622). Fifty years later, in 1672, an English ship arrived in Falmouth from Jamaica, reporting to the London Gazette 'that he met off of the Northern Cape, an Algiers man of War, who Treated him with much kindness; telling him of some Sally men of War that were abroad that way, upon which 
advice he altered his course, and so missed them' (London Gazette, 11-15 April 1672). ${ }^{1}$ In 1696, the famous business periodical Collection for the Improvement of Husbandry and Trade devoted an entire page to explaining why trade with the Maghrebi coast should be an English priority: being 'one of the fruitfullest Countries in the World', from where 'we might have ... Gold, Copper, Estrich-Feathers, Dates, Almonds, Wax, Gums, Horses, Goat and other Skins in abundance' and improved access to trade with Spain, the Canaries, Saharan Libya and Guinea, and where 'if we should get all the Trade that a Probability may be shown for; we should out-do all our Neighbours' (Collection for the Improvement of Husbandry and Trade, 21 February 1696).

It is well established in recent historiography that the privateering corsairs of the early modern Maghreb (modern Morocco, Algeria, Tunisia and Libya, in Figure 1 as Morocco, Fez, Algier, Tunis, and Tripoli) were powerful and dangerous to their enemies, but typically reliable and loyal to those with whom they established peace. Authorised and licensed by recognised states and governed by treaties, Maghrebi corsairs participated in a Mediterranean-wide system of ad hoc naval warfare practiced by Protestants, Catholics and Muslims alike during periods between major military altercations (see Klarer 2019, pp. 1-8; Akihito and Atsushi 2018, pp. 20-26, 42; Kaiser and Calafat 2014, pp. 78-82; Stein 2015, pp. 603-4; Matar 2001a, pp. 7-9; Matar 2003, pp. 57-58; Lofkrantz and Ojo 2016, pp. 1-22 and passim; Backman 2014, pp. 180-82). Just as Europeans were taken captive by Maghrebi corsairs, so too were Maghrebis captured by Europeans (Matar 2005, pp. 118-32; Panzac 2005, pp. 21-23; Klarer 2019, pp. 5-6). Formerly in a largely adversarial relationship with Christian Europe, throughout the seventeenth century the Maghrebi states established stable treaties of peace and trade with the Atlantic states of France, England and the Dutch Republic, and increasingly integrated themselves into the Mediterranean trading system (Hershenzon 2018, pp. 186-90; Akihito and Atsushi 2018, pp. 26-29; Kaiser and Calafat 2014, pp. 79-84; Meyers 1977; Hunter 1999, pp. 5-17). Walter Rech has shown that, in addition to being recognised at this practical diplomatic and military level, a growing majority of early modern European legal scholars also accepted the status of the corsairs as legitimate privateers, either following French lawyer Jean Bodin in recognising the sovereign rights of Maghrebi nations to license violence, or resorting to a range of historical arguments which placed Maghrebi privateers as justly violent self-defending combatants in an everlasting, ancestral conflict between Christians and Muslims (Rech 2019; see also Akihito and Atsushi 2018, pp. 28-29; Calafat 2011; Tucker 2019).

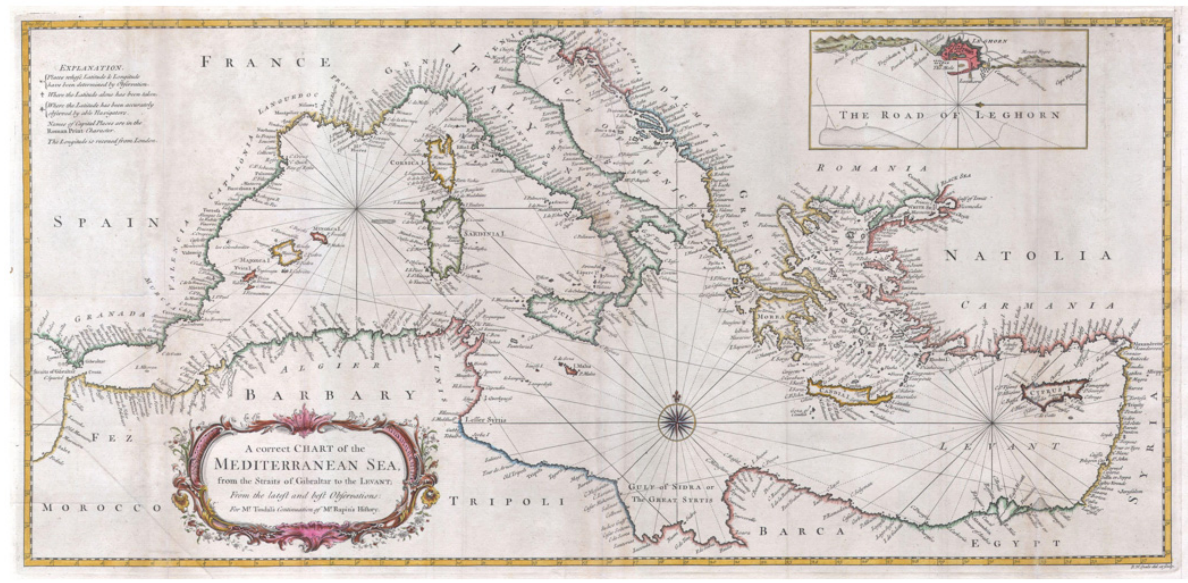

Figure 1. Richard William Seale, A correct Chart of the Mediterranean Sea, from the Straits of Gibraltar to the Levant: From the latest and best Observations: for Mr. Tindal's Continuation of Mr. Rapin's History, 1745, ink on paper, $35.56 \times 72.39 \mathrm{~cm}$.

1 It is instructive, in light of analysis below, that the same naval term 'man of war' is being used for both enemies and friends. 
However, as John-Paul Ghobrial has observed, what European people knew about the Ottoman Empire (and by extension, neighbouring Morocco) 'necessarily depends on what sorts of people we have in mind, when and where they lived, and what exactly motivated their interests in distant lands' (Ghobrial 2013, p. vii). The shifting realities of Maghrebi warfare, diplomacy, and trade are rarely acknowledged to have penetrated British society far beyond the relatively small number of politicians, diplomats, merchants, captives, sailors, and soldiers among whom it was of direct concern or experience. Through fiction, propaganda, rumour, misunderstanding and deliberate misinformation, British popular audiences developed a view of the Maghrebi nations as barbaric, chaotic, cruel and unmanageable (see, e.g., Matar 2001b, pp. 2-6; Ghobrial 2013, pp. 8-10). Postcolonial historian Lofti ben Rejeb contends for an overwhelming "Barbary discourse" in British popular thought that 'fixed North Africa as an unchanging locus of barbarism and enmity towards Christendom that had to be fought and conquered'. Thus there was, in his assessment, 'a profound disjunction between the historical realities of Mediterranean life and the simplified picture that was systematically projected,' since 'sustained commercial relations and frequent political alliances between the shores of the Mediterranean negated some of the most enduring notions of the Barbary discourse, such as the idea that relentless fanaticism drove North African rulers and peoples, or the idea that piracy was their sole occupation and economic lifeblood' (Ben Rejeb 2012, pp. 18-19). ${ }^{2}$ Similarly, Wolfgang Kaiser and Guillaume Calafat argue that the Barbary corsairs, 'accused in European sources of violent usurpation of power and of being by nature untrustworthy', were simultaneously those with whom 'the European powers developed the earliest modern forms of regulation and protection of the freedom of navigation and trade' (Kaiser and Calafat 2014, p. 85). A large part of this disjuncture, as it has been framed in historiography, is the lack of reliable information that was made available to a wide audience. Historians have recognised somewhat more accurate published accounts in captivity narratives, printed articles of peace, and once-off pamphlets reporting particular naval battles or the ongoing state of English Tangier (1661-1684), but these were few in number and often difficult to access (Cutter 2018, pp. 62-63; Matar 2005, pp. 148-49). For the vast majority of the British population, learning of the Maghreb from fiery sermons, wandering players and the fiscally-motivated collectors of donations for redeeming British captives in the Maghreb, the corsairs were 'cruel infidels who compelled Christians, with torture and savagery, to renounce their much-loved God and monarch' (Matar 2001b, p. 25; see also Maclean 2007, pp. 95-96; Matar 1999, pp. 5-8, 13-14; Matar 2001a, p. 243). Daniel Vitkus, examining one-off pamphlets presented as news, argues that even these ostensibly factual accounts 'present and confirm the Western stereotype that associates Islam with acts of violence, treachery, cruelty, and wrath', painting Muslims as 'ranting, irrational, fanatical killers who practice treachery, oath-breaking, double-dealing, enslavement, piracy, and terrorism' (Vitkus 1999, p. 207-30).

One corpus, however, neglected in the study of British views of the Maghreb, tells a rather different story (see Cutter 2018, pp. 64-65). ${ }^{3}$ The seventeenth century witnessed an explosion in printed English-language periodicals, and these publications were positively devoured by British audiences: some 31,000 individual issues appeared before 1700 and, by 1704, London presses were churning out an estimated 40,000 copies every week (Nelson and Seccombe 1987, p. vii; Berry 2000, p. 17; Raymond 2011b, pp. 383-94; Maclean 1995, p. 243). ${ }^{4}$ Although these periodicals disproportionately

2 (Nabil Matar 1999, pp. 5-18, 170) argues that this essentialising discourse, drawing heavily on colonialist perceptions of Amerindians, actually strengthened over the seventeenth and eighteenth century, before reaching its fullest form in nineteenth-century Orientalism. Both Ann (Thomson 1987, pp. 1-32; Asli Çirakman 2005, pp. 2-3) perceive a linear movement from sixteenth-century ignorance to nineteenth-century Orientalism.

3 To this assessment may be added another "side-glance" use of newspapers in the discussion of seventeenth-century Maghrebi corsairing: Michael Guasco, Slaves and Englishmen: Human Bondage in the Early Modern Atlantic World (Philadelphia: University of Pennsylvania Press, 2014), 126; and the more significant use of the London Gazette in relation to Istanbul in Ghobrial, Whispers of Cities, pp. 122-58.

4 I have used the term 'printed periodicals' deliberately to exclude once-off news pamphlets and manuscript newsletters, and to focus on those publications which were designed to provide a regular, consistent and reliable flow of news to their readers. 
aimed at, and reached, literate, male, middling-sort urbanites, these publications were passed between acquaintances and read aloud in coffee-houses and public squares, such that they affected a much larger proportion of the population. With foreign news based on eyewitness accounts, the major newspapers gained a reputation for freshness and reliability to the extent that they were used as journals of record for court cases and historical research (Cutter 2018, pp. 64-69; Glaisyer 2017, pp. 262-64). The scholarly neglect of periodical news in relation to the Maghreb can be partly attributed to a common focus in studies of English attitudes towards religious and racial difference, driven by experts in Shakespeare and his contemporaries, on the period of the late sixteenth and early seventeenth centuries (see for example Burton 2005; Matar 1999; Bartels 2008; McJannet 2006; Dimmock 2016; Hwang Degenhardt 2010; Andrea and McJannet 2011; Robinson 2007; Vitkus 2003). While some English periodical publications focusing on foreign news emerged in the early 1620s, and for relatively short periods during the War of the Three Kingdoms and the later Commonwealth, the vast majority of extant news articles relating to the Maghreb date from after the Restoration in 1660 (Table 1). Another problem is the issue of volume. To take a recent example, Gary K. Waite's recent study of Dutch and English attitudes towards Jews and Muslims focuses on just 120 Dutch pamphlets; precisely because 'the number of pamphlets produced each year grew dramatically after 1648', Waite is 'much less comprehensive in coverage for the second half of the century' (Waite 2019, p. 4). This article examines just English-language newspapers relating to the Maghreb, but even then the numbers are significant. Using fine-grained text searches on three digital news databases, I have collected for this study some 3385 news items, totalling over 360,000 words. ${ }^{5}$

Table 1. Articles relating to the Maghreb by period.

\begin{tabular}{cccc}
\hline Period & Articles & Average Per Year & \% of Total \\
\hline $1622-1660$ & 106 & 2.7 & $3.13 \%$ \\
$1661-1680$ & 1010 & 50.5 & $29.84 \%$ \\
$1681-1682$ & 434 & 217.0 & $12.82 \%$ \\
$1683-1703$ & 1240 & 59.0 & $36.63 \%$ \\
$1704-1714$ & 595 & 54.1 & $17.58 \%$ \\
Total & 3385 & 36.4 & $100.00 \%$ \\
\hline
\end{tabular}

This material, as I have argued elsewhere, is useful for the study of British perceptions of the Maghreb for four major reasons (Cutter 2018, pp. 64-83). Firstly, this store of material, in terms of volume, breadth of coverage and number of individual items, numbers among the most significant corpora relating to English perceptions of the Maghreb in the Stuart era. Secondly, periodical news publications held a rare combination of extremely broad circulation and significant public trust, making this material vital for understanding how information and views of the Maghreb were disseminated throughout a large and diverse segment of the population. Thirdly, since this material was sourced from, edited by, and largely aimed towards (though certainly not only received by) the wealthy and powerful power-brokers of England's mercantile, diplomatic, and naval community, it provides unrivalled access to the information and views that shaped actual British relations with the Maghreb. Fourthly, and perhaps most importantly, this material offered to its readers consistently robust, detailed, and largely polemic-free coverage of ethnic, political and religious diversity in the Maghreb, against modern historiography that claims prejudice-laden terms like "Turk" stood in not just for all Muslims but 'the enemy, any enemy ... Catholics, anti-Catholics, the French, Presbyters, Jesuits, Jews, and the Devil himself' (Sisneros 2016, pp. 262-63). In this present paper, I extend the discussion of English periodical news coverage of the Maghreb to the hard-nosed worlds of maritime combat, diplomacy, and

5 London Gazette available at https://www.thegazette.co.uk; Burney Collection available at https://www.gale.com/uk/c/17thand-18th-century-burney-newspapers-collection; Nichols Collection available at https://www.gale.com/c/17th-and-18thcentury-nichols-newspapers-collection. 
trade between European and the Maghreb. I argue that newspapers provided an important corrective to Ben Rejeb's "Barbary discourse", presenting material to seventeenth- and early eighteenth-century British audiences that portrayed a broadly equitable balance of naval aggression between Europe and the Maghreb, shifting yet increasingly constructive diplomatic relations, and a clearly-growing economic interdependence between the Northern and Southern shores of the Mediterranean, even to the extent of over-emphasising Britain's positive connections to the Maghreb. ${ }^{6}$ Periodical news publications thus offered evidence to their readers that the Maghreb was neither undifferentiated nor unchanging.

\section{Preliminary Analysis}

Early British newspapers devoted a great deal of coverage to the movements of enemy and friendly military forces, political and diplomatic developments abroad, and the arrival and departure of ships importing and exporting goods to Europe and beyond, as well as local court affairs and an increasing raft of advertisements for books, events and sales of all kinds (Cutter 2018, pp. 66-67; Black 2001, pp. 123-26). The coverage of the Maghreb, in many ways, was similar to many regions, particularly those outside of Europe: Maghrebi relations with Europe surrounding maritime trade and warfare, and the diplomacy designed to promote the one and prevent the other, predominated. Of the 3385 articles in my corpus, 2584 (76.34\%) partly or wholly relate to Maghrebi maritime combat, diplomacy and trade with Europe; the remainder being concerned with local Maghrebi politics and land-based military affairs (e.g., against the Spanish presidios of Ceuta, Melilla and Oran). For the purposes of this paper, I will briefly examine the whole scope of coverage in a quantitative manner, before taking a more particular, qualitative look at how British newspapers present their own nation's relations to the Maghrebi states, which would naturally have been of greater interest to British readers. Naval warfare is by far the largest topic on this theme reported in the newspapers, with some 956 references of various lengths in my corpus to European (including British) attacks on Maghrebi targets, and 929 to Maghrebi attacks on Europeans, for a total of 1885 references (Table 2, Figure 2). ${ }^{7}$ We can see that a minority of maritime combat references relate to British combatants, but whether we look at British or other European combatants, the balance of aggression/victory is roughly equal between European and Maghrebi attacks. Both diplomacy and peaceful trade receive a surprising number of references-1113 and 537, respectively-and the majority of both relate to British-Maghrebi relations (Table 2). ${ }^{8}$ These figures, at a very basic level, indicate that news coverage of the Maghreb was by no means limited to the aggression of Maghrebi corsairs against European victims: there was plenty of opportunity for European aggression and retaliation, as well as fruitful negotiation for peace and mutual economic benefit, and these latter subjects were either of special interest to British readers, or for other reasons deliberately emphasised by news writers. A similar theme can be observed in the various terms used by news writers to describe Maghrebi ships at sea (Tables 3 and 4). Comparing the number of articles using terms that suggest illegitimate or unlicensed maritime predation (pirate, rover), legitimate or licensed maritime predation (corsair, privateer), official naval activity (man of war, admiral), and terms with a neutral or undetermined tone (ship, boat, galley, barque, brigantine, caravel, ketch, pink, polacca) indicates shifting classifications of Maghrebi piracy across the period,

6 This paper will not consider land warfare against European presidios in the Maghreb, relations among Maghrebi states or between Maghrebi states and the Ottoman Empire, or local Maghrebi news, though there is significant evidence that British newspapers reported on these events as well-see (Cutter 2018, pp. 76, 78-81).

7 Since in most cases, maritime combat was ongoing, and presented as retaliation or precaution against the others' aggressions, I have chosen to organise the cases based on the instigator, and in cases where the instigator is unclear, the eventual victor. The aggressor count also includes references to naval preparations intended against the opposing side, even when framed as retaliation.

8 In both these cases, I have taken a somewhat broad definition: 'diplomacy' includes all references to intended or actual diplomatic activity, as well as references to Maghrebi diplomats engaging in less strictly diplomatic activities while in Europe; and 'peaceful trade' includes references ranging from brief reports of Italian merchant ships arriving with messages from Tunis up to page-long treatments of the advantages of trade with the Maghreb. 
but at the very least that Maghrebi conflict at sea was more often spoken about in terms of licensed predation (used in 449 articles) than illegitimate (345 articles), and at times naval terms (322 articles) also outpaced illegitimate. Both of these general themes can be clarified and expanded by looking in detail at British relations with the Maghreb.

Table 2. References to maritime combat, diplomacy and trade (British and European relations).

\begin{tabular}{lcccc}
\hline Topic Category & $\begin{array}{c}\text { Total } \\
\text { References }\end{array}$ & $\begin{array}{c}\text { Continental } \\
\text { Europe }\end{array}$ & Britain & Britain \% \\
\hline Maritime Combat (European attack) & 956 & 676 & 280 & $29.29 \%$ \\
Maritime Combat (Maghrebi attack) & 929 & 723 & 206 & $22.17 \%$ \\
Maritime Combat & 1885 & 1399 & 486 & $25.78 \%$ \\
Diplomacy & 1113 & 482 & 631 & $56.69 \%$ \\
Peaceful Trade & 537 & 230 & 307 & $57.17 \%$ \\
\hline
\end{tabular}

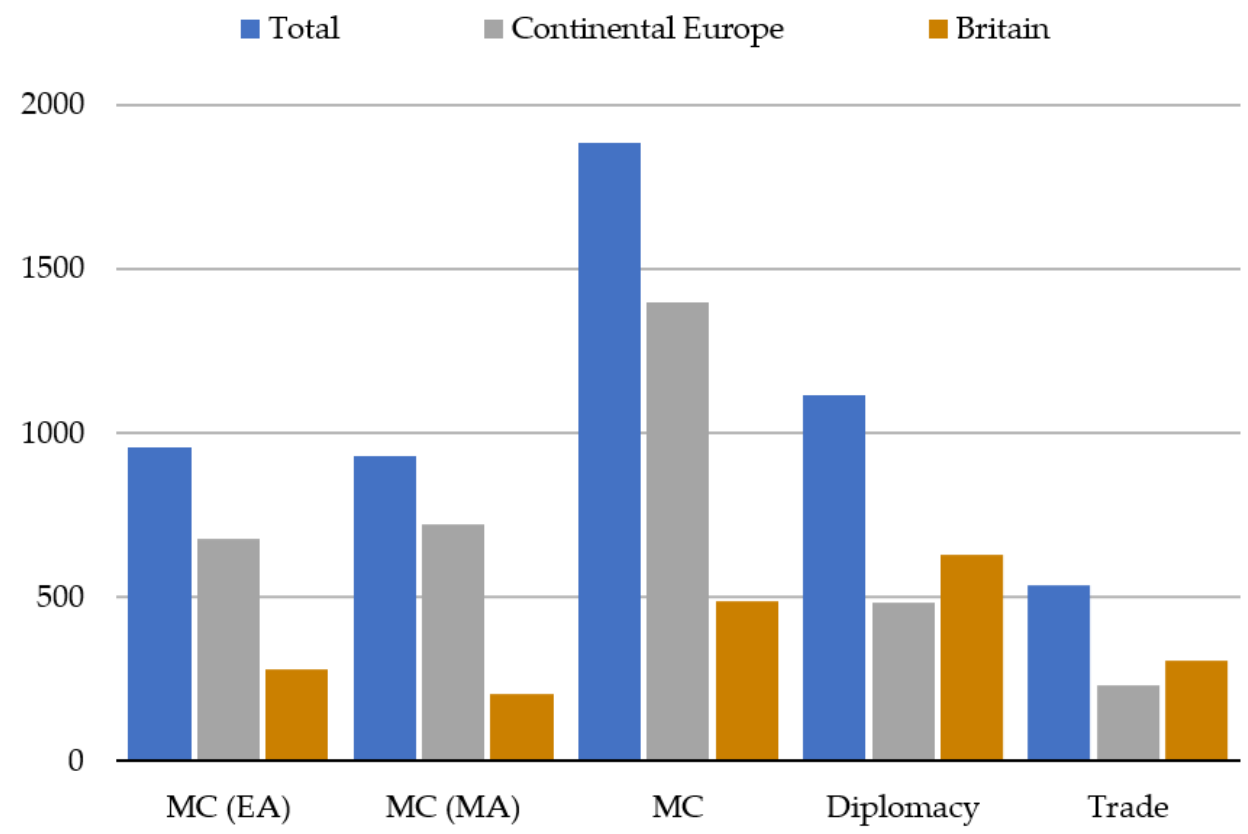

Figure 2. References to maritime combat, diplomacy and trade (British and European relations).

Table 3. Classifications for Maghrebi ships at sea (number of articles employing term, highlighting most common category in each period).

\begin{tabular}{lcccccc}
\hline Term & $\mathbf{1 6 2 2 - 1 6 6 0}$ & $\mathbf{1 6 6 1 - 1 6 8 0}$ & $\mathbf{1 6 8 1 - 1 6 8 2}$ & $\mathbf{1 6 8 3 - 1 7 0 3}$ & $\mathbf{1 7 0 4 - 1 7 1 4}$ & Total \\
\hline Pirate & 41 & 88 & 23 & 40 & 21 & 213 \\
Rover & 4 & 1 & 6 & 93 & 35 & 139 \\
Illegitimate & $\mathbf{4 4}$ & 89 & 29 & $\mathbf{1 3 0}$ & 53 & 345 \\
Corsair & 1 & 224 & 18 & 102 & 57 & 399 \\
Privateer & 0 & 17 & 2 & 16 & 33 & 68 \\
Licensed & 1 & $\mathbf{2 2 9}$ & 20 & 116 & $\mathbf{8 3}$ & $\mathbf{4 4 9}$ \\
Man of War & 3 & 173 & 29 & 58 & 11 & 270 \\
Admiral & 1 & 19 & 3 & 20 & 10 & 52 \\
Naval & 4 & 189 & $\mathbf{3 2}$ & 74 & 21 & 322 \\
Ship etc. & 20 & 71 & 7 & 36 & 18 & 152 \\
\hline
\end{tabular}


Table 4. Classifications for Maghrebi ships at sea (\% of articles employing term within entire corpus, highlighting most common category in each period).

\begin{tabular}{ccccccc}
\hline Term & $\mathbf{1 6 2 2 - 1 6 6 0}$ & $\mathbf{1 6 6 1 - 1 6 8 0}$ & $\mathbf{1 6 8 1 - 1 6 8 2}$ & $\mathbf{1 6 8 3 - 1 7 0 3}$ & $\mathbf{1 7 0 4 - 1 7 1 4}$ & Total \\
\hline Pirate & $38.68 \%$ & $8.71 \%$ & $5.30 \%$ & $3.23 \%$ & $3.53 \%$ & $6.29 \%$ \\
Rover & $3.77 \%$ & $0.10 \%$ & $1.38 \%$ & $7.50 \%$ & $5.88 \%$ & $4.11 \%$ \\
Illegitimate & $\mathbf{4 1 . 5 1 \%}$ & $8.81 \%$ & $\mathbf{6 . 6 8 \%}$ & $\mathbf{1 0 . 4 8 \%}$ & $8.91 \%$ & $10.19 \%$ \\
Corsair & $0.94 \%$ & $\mathbf{2 2 . 1 8 \%}$ & $4.15 \%$ & $8.23 \%$ & $9.58 \%$ & $11.79 \%$ \\
Privateer & $0.00 \%$ & $1.68 \%$ & $0.46 \%$ & $1.29 \%$ & $5.55 \%$ & $2.01 \%$ \\
Licensed & $0.94 \%$ & $\mathbf{2 2 . 6 7 \%}$ & $4.61 \%$ & $9.35 \%$ & $\mathbf{1 3 . 9 5 \%}$ & $\mathbf{1 3 . 2 6 \%}$ \\
Man of War & $2.83 \%$ & $17.13 \%$ & $6.68 \%$ & $4.68 \%$ & $1.85 \%$ & $7.98 \%$ \\
Admiral & $0.94 \%$ & $1.88 \%$ & $0.69 \%$ & $1.61 \%$ & $1.68 \%$ & $1.54 \%$ \\
Naval & $3.77 \%$ & $18.71 \%$ & $7.37 \%$ & $5.97 \%$ & $3.53 \%$ & $9.51 \%$ \\
Ship etc. & $18.87 \%$ & $7.03 \%$ & $1.61 \%$ & $2.90 \%$ & $3.03 \%$ & $4.49 \%$ \\
Corpus articles & 106 & 1010 & 434 & 1240 & 595 & 3385 \\
\hline
\end{tabular}

\section{British Relations with the Maghreb}

\subsection{Power and Payments, $1622-1660$}

In the early Stuart and Commonwealth periods, Maghrebi corsairs were at the apogee of their power, and the English struggled to establish rapprochements with Maghrebi governments, or achieve significant results by naval retaliation (Akihito and Atsushi 2018, p. 26; Kaiser and Calafat 2014, pp. 75-79; Matar 2001a, pp. 239-58; Matar 2001b, pp. 7-8; Matar 2005, pp. 38-39; Davis 2009, p. 34). The Levant Company, despite its official monopoly over English trade with the Ottoman Empire and its semi-autonomous "Regencies" in Algiers, Tunis and Tripoli, for all intents and purposes withdrew from the Maghreb in 1625 after the mistreatment of its agents in Algiers, meaning only very few English merchants ventured to trade directly between England and the Maghreb (Barbano 2018; Bak 2000, pp. 53-82; Matar 2005, pp. 59-62; Stein 2012, pp. 31, 41-49, 353-56). Maghrebi corsairs regularly raided the coasts of England and Ireland, famously carrying off the entire Irish village of Baltimore in 1631 (Murray 2006; Matar 2014, pp. 75-112). ${ }^{9}$ According to Nabil Matar:

By seizing on English or Welsh, Irish or Scottish merchants and travelers, the Moors and the Turks produced an image of a dangerous "Mahumetan" world in the minds of the British reading, traveling, trading and sailing public. As a result, and instead of viewing themselves as rulers of the waves, Britons were forced to compromise with Muslims, and to negotiate and bargain, plead and appeal—even to submit to the forceful might of the corsairs. (Matar 2005, p. 73)

As noted above, periodical publications focusing on foreign news really came into their own after 1660; however, there are some examples from an earlier period (Raymond 2011b, pp. 377-97). In the brief, factual, limited periodical coverage relating to the Maghreb from this period (106 articles, Table 1), there is a sense of weary resignation to the Maghrebi threat: 'about 70 Saile of Turkish Pyrats are lately come out of Algier and Tunis in Barbery, whereof about forty are come towards the coasts of England and France, and ply up and down those Seas for booty' (Certaine Informations from Severall Parts of the Kingdom, 10-17 July 1643). Newspaper coverage of Maghrebi-European relations in this period was heavily geared towards maritime combat, with 90 references per 100 articles, compared to 21 per 100 for diplomacy and 11 per 100 for peaceful trade (Table 4). Several diplomatic expeditions did successfully organise the redemption of British slaves from the Maghreb, some of which are reported in the newspapers. For example, in 1647:

9 Algerian corsairs even ventured as far north as Iceland (Helgason 2018). 
There came lately from Algiere (a sea town in the Mediterranian, upon the African side, where is resident a Turkish Bassaw, as Governour, who hath all Turks in Command under him; the Pirates of this Town, for so they are called, because the Grand Seignior [i.e., the Sultan of the Ottoman Empire] doth not own their taking of Ships from other States) a Ship called the Charles, Commanded by Captain Will. Weildy, who brought 175 Captives redeemed out of slavery (being the second Ship that hath acted in this good work) the Captives were redeemed by monies advanced upon an Ordinance, which imposeth 5 per Cent. upon certain Merchandise; these redeemed ones attended lately the Parliament, giving them thanks for so great a favour afforded. (Moderate Intelligencer, 23-30 September 1647) ${ }^{10}$

Under Charles I's personal rule (c.1629-1640) and the Commonwealth (1649-1660), strict censorship was applied to periodical news. This perhaps goes to explain why, despite successful attacks on Salé in 1637 and Porto Farina (Ghar al-Milh) in 1655, just one reference, from 1641, appears in the corpus to British attacks on Maghrebi targets: 'an humble suit was made by the House of Commons ... to the King, that he would be pleased to send two of his Ships which were upon the Western parts, to remove some Turkish Pirates which had taken some English, and sent them to Argiere, and lye in wait to take more. Unto which, answer was presently returned, they should be sent away forthwith' (Diurnal Occurrences or Daily Proceedings, 3 November 1640-1649 September 1641). It was in this period that terms branding Maghrebi ships as illegitimate were most prevalent, appearing in $41.51 \%$ of articles (Table 4).

Because of the overall paucity of material, only very basic conclusions can be drawn about this period. It seems likely that, before the Restoration, periodical news provided only one small voice among many describing the Maghreb for British readers, but such coverage as was available was broadly consistent with the significant threat Maghrebi corsairs posed to British shipping, and the limited peaceful exchanges that took place between them.

\subsection{Combat and Negotiation, $1660-1680$}

For both periodical news and British-Maghrebi relations, the years surrounding the Restoration of Charles II in 1660 were a watershed. The later Commonwealth and Restoration governments undertook to provide an official flow of news while suppressing unofficial media, and from 1655 onwards launched a succession of official government newspapers. Based on diplomatic correspondence and published from the office of the Secretary of State, these papers culminated in the bi-weekly Oxford then London Gazette in 1665, which continues to be published today (see Glaisyer 2017; Handover 1965; Williams 1977; Sutherland 1986; Cowan 2004, p. 35). In the same period, building on naval and diplomatic reforms made under the Commonwealth, England's naval and economic power in the Mediterranean grew, and, recognising Maghrebi autonomy under the Ottoman Empire, peace was negotiated directly with the Ottoman Regencies of Tunis and Tripoli in 1662 and Algiers in 1662 and 1664 (Akihito and Atsushi 2018, pp. 26-29; Kaiser and Calafat 2014, pp. 82-84; Panzac 2005, pp. 25-39; Matar 2005, pp. 9-11). ${ }^{11}$ Simultaneously, Charles II received, through his marriage to Catherine of Braganza, the Portuguese-controlled outpost at Tangier, and he and his government quickly moved to establish it as a vital naval, military and economic base on the Moroccan side of the Strait of Gibraltar. By the mid-1660s, England had apparent peace with all four major territories of the Maghreb, and the future of trade seemed bright (Akihito and Atsushi 2018, pp. 26-27; Stein 2015, pp. 606-9; Brown 2008, pp. 602-6; Hunter 1999, pp. 5-17, 22-23; Matar 2014, pp. 113-32; Ghobrial 2013, 26-27; Hershenzon 2018, p. 188; Beijit 2015, pp. 1-57). The London Gazette reported in 1666 that the Governor of Tangier

10 It is instructive to note the careful definition of 'pirate' here, which allows that they might be considered legitimate privateers if England had recognised Algiers as an autonomous state, rather than a subordinate province of the Ottoman Empire; the status of Algiers in English opinion was to change rapidly after the Restoration. See also Faithful Scout, 23-30 January 1652.

11 The French observed a similar diplomatic pattern in the 1660s (McCluskey 2009). 
had 'certainly concluded a Peace' with Khidr Ghaylan, the local warlord, and 'the Garison is plentifully supplied with all sorts of Provisions from the Moors, who daily flock thither in great numbers, and vow to preserve the Peace inviolably' (London Gazette, 26-30 April 1666). In the same issue, a ship arrived in Falmouth 'with Fruit and Wine from Tangier, who speaks much of the advantages of the place, for landing and receiving Goods' and reported that the Algerian, Tunisian and Tripolitan corsairs 'are very civil and serviceable to us in the Streights, and have taken several French Vessels, carrying them into Tangier, where they have liberty to sell them; and that they chaced in one with Sugars from Brasil, which proved a good prize' (London Gazette, 26-30 April 1666). The conclusion of treaties also meant massive exchanges of prisoners. In 1663, the government-run Kingdomes Intelligencer reported the redemption of captives following a treaty with Algiers in jubilant tones: 'We formerly told you of the pious resolution of the most Reverend the Archbishops, Bishops, Deans, and Chapters of the Church of England, to redeem all such Captives as were Slaves in Algiers, Tituan, \&c. who had been Subjects to his Majestie the King of Great Brittain. And now we can give you a perfect account how that happy and Christian work is effected [with] our wellbeloved friends the AgaYa Bashaws and the rest of the honorable Council of State and War in the City and Kingdom of Algiers' (Kingdomes Intelligencer, 12-19 January 1663).

From the late 1660s, the London Gazette repeatedly reported with fascination how English ships met with Maghrebi corsairs in the Mediterranean, but were not mistreated. In 1672, four English ships returned from the Mediterranean and reported 'that they met with an Argiers man of War, who offered them not the least violence, but on the contrary, used them with much Civility; from which Treatment of the Turks; we conclude, that Sir Edward Spragge hath certainly concluded a peace with them' (London Gazette, 15-18 January 1672). In 1668 alone, a London ship coming from the Venetian island of Zante (modern Zanthykos, Greece) 'in her way homewards met with several ships belonging to Algier, Tunis, and Tripoli, who dismist her without any the least disturbance'; a second lost its convoy from Spain, and 'was afterwards met by five Turks Men of War, who haling her, and enquiring onely what she was, immediately dismist her with much civility'; and a Venetian ship 'having aboard them an English young man, who passed with the Turks for Master of the ship ... in the dark escaped [capture], upon the pretence of being English' (London Gazette, 3-6 February 1668; 14-17 December 1668; see also numerous other incidents in London Gazette, 6-9 April 1668; 20-24 August 1668; 31 August-3 September 1668; 14-17 September 1668; 8-11 March 1669; 3-7 June 1669; 12-16 August 1669; 23-26 August 1669; 9-13 September 1669).

England's new treaties were printed in the newspapers and republished in special issues: successful peace negotiations with the dangerous naval powers of the Ottoman Regencies were evidently both joyful news and vital information for all involved in maritime trade and warfare. The London Gazette introduced a 1676 treaty with Tripoli in the following way: 'We have by two Posts successively received the confirmation of Sir John Narbrough's having on the 5th of March past, concluded a Peace with the Governor of Tripoli, so much to the Honour of his Majesty, and to the Advantage of the whole Nation in its Trade and Navigation; together with the Copy of the Articles, which in substance are ... ' (London Gazette, 13-17 April 1676; see also Kingdomes Intelligencer, 23-30 June 1662). Though in this and other initial reports of treaties, the newspapers faithfully recorded treaty articles which acknowledged Maghrebi responsibility for the commencement of conflict, ${ }^{12}$ reports of peacetime diplomatic visits deliberately emphasised stability and positive treatment at the hands of Maghrebi governments. In 1668, Sir William Jennings visited Algiers with the English fleet and 'was very civilly Treated by the Governor and Magistrates of that place, all of them expressing their hearty resolution to preserve the peace formerly made with his Majesty of Great Britain' (London Gazette, 4-8 June 1668); and in 1669, Sir Thomas Allin and the fleet visited Tunis, and 'were civilly Treated by the Dey, who has

12 London Gazette, 13-17 April 1676, point XIX contains a reasonably summary of article XIX in the original treaty included in (Parry 1969-1980, vol. 14, pp. 79-80). See also Kingdomes Intelligencer, 23-30 June 1662, which contains a broadly faithful summary of the 1662 treaty with Algiers, cf. Parry 1969-80, 7: 175-79. 
declared his resolution of maintaining the peace with England according to former Articles, the people there desiring nothing more than to continue their Traffique and Commerce with the English' (London Gazette, 22-25 November 1669; see also for Tripoli London Gazette, $13-17$ January 1670). ${ }^{13}$ This repeated reporting of England's separate diplomatic relations with each of the Ottoman Regencies brings forward by more than forty years the shift that Matar locates in the War of the Spanish Succession, where British 'dealings with the Muslim potentates and courts were not painted with a religious brush' but 'Christian-Muslim relations had become British-Algerian, British-Tunisian, or British-Moroccan relations' in the face of Britain's insatiable imperial goals (Matar 2008, pp. 292-93, 299-300; see also Cutter 2018, pp. 79-80). Though Tangier inspired a certain amount of imperial hope see (Beijit 2015, pp. 1-57), England in the 1660s could hardly be said to have the same imperial power or imperial vision in the Mediterranean as it did after colonising Gibraltar and Minorca in the early eighteenth century, so in this respect, Matar's connection between British imperialism and a public face of positive engagement with the Maghrebi states must be re-evaluated.

Unfortunately for the cause of ongoing peace, the elaborate system of official passes issued by British monarchs for safe passage established by the 1660s treaties (the so-called 'sea of paper'), and worked out in everyday encounters at sea, was not based on sufficient mutual trust to maintain stability (Kaiser and Calafat 2014, pp. 82-85; Matar 2001b, p. 31; Davis 2009, p. 35). ${ }^{14}$ Tristan Stein emphasises the instability of this period:

rival interpretations of treaty articles and difficulties determining the actual provenance of particular vessels led to regular outbreaks of violence between England and the regencies, culminating in a long and costly war with Algiers [in 1677-1682] ... Although England enjoyed notable military successes, especially against Tripoli, these conflicts illustrated its inability to impose lasting terms on either Morocco or Algiers. (Stein 2015, pp. 610-11; see also Matar 2010)

Significant tensions began to be reported as early as 1669, when a ship arrived in Yarmouth, whose captain reported:

that off the North Cape they met with an Algier man of War of 36 Guns, who sent their boat aboard them, and made a strict search, but that the Master of this ship and the Merchant going aboard the Turks man of War were civily Treated, and offered a supply of any necessaries they could furnish them with, excusing the strictness of the search upon several abuses put upon them by such of their Enemies as had pretended their ships and goods to have been English. (London Gazette, 29 March-1 April 1669; see also London Gazette, 10-13 May 1669)

Uncertainty over negotiations afoot in Algiers that year tempted an Algerian corsair to capture an English ship, who 'made at the first some difficulty of letting her pass, but, in conclusion, dismist her, saying, They would not that any breach should be on their part' (London Gazette, 4-7 October 1669). As mentioned above, this period saw significant conflict with Algiers and Tripoli, as well as smaller-scale conflicts with the corsairs of Moroccan Salé. News writers took the opportunity of victorious combat to print long and dramatic accounts of English naval triumphs, which stand in stark contrast to the brief, bleak reports of the previous periods. ${ }^{15}$ A briefer example of this trend appeared in the London Gazette in 1668:

The Seas are of late well secured from the Sally Men of War by the diligence of Captain Richard Rooth, who with the Garland and Francis Frigats cruising upon their Coasts, on the

13 Of course, in reality it is hardly like that all 'the people' of Tunis desired 'nothing more' than peace with the English; this presentation clearly exaggerates diplomatic niceties for popular audiences.

14 The definitive article on Mediterranean passes and their role in British relations with the Maghrebi states is (Stein 2015).

15 (Matar 2005, pp. 150-58) has recognised a similar trend, 'a wide interest in eyewitness accounts and [a] deep-seated desire to valorize British warriors and annihilate the unnamed and unknown Moors', in a small flurry of accounts relating to Tangier that appeared around 1680. 
25th of September last forced a Pink with 8 Guns and about 80 men, with her Prize, another Pink of 70 or 80 Tons, belonging to Dublin, over the Barre of Sally, within the Command of the Castle; which fired many Guns for their rescue: but the Pinks striking several times on the sands, both of them sunk upon their entrance. (London Gazette, 19-23 November 1668) ${ }^{16}$

Algiers in particular was an extremely dangerous enemy: even after making peace with England, it still maintained 'an imposing fleet comparable to that of European navies', and had the expertise to use it (Panzac 2005, p. 41). When war broke out in 1678, after numerous treaty violations by individual English captains, the Algerians prosecuted it with devastating effect. In 1680, an anonymous English resident in Algiers reported in a letter to Mercurius Civicus:

Since my last, these following Ships were brought up hither, 7 English Ships with Sugar and Tobacco, coming from the Barbados, and two going thither; ten Laden with Fish from New-found-Land, two with Iron and Wooll, one with Hemp, Flax and Fish, one with Iron, Liquors, and other Wares, going for Guiney: The number of men on board these Ships were two hundred and ninety. (Mercurius Civicus, 22 March 1680)

Despite all this conflict, the balance of newspaper coverage emphasises that this was not the chaotic and unmanageable Maghreb feared in the earlier parts of the century: as a general rule, disputes were carefully resolved according to the rules, and when negotiations broke down, war was officially declared in accordance with the treaties (Kaiser and Calafat 2014, pp. 82-84). Maghrebi-European maritime combat remained the most significant topic ( 83 references per 100 articles), but both diplomacy (29 per 100 ) and peaceful trade (12 per 100) were increasing in prominence (Table 5, Figure 3). Newspapers were also starting to report more specifically on British-Maghrebi relations, which previously had been marginal within the overall coverage of European-Maghrebi relations: from accounting for 20.93\% of overall references in 1622-1660, to $43.84 \%$ in 1660-1680 (Table 5). During this period, there is also a dramatic decline in uses of illegitimate terms to describe Maghrebi ships at sea, from $41.51 \%$ of articles in $1662-1660$ to $8.81 \%$ in $1661-1680$, in favour of a significant increase in licensed $(0.94 \%$ to $22.67 \%$ ) and naval (3.77\% to $18.71 \%$ ) terms (Table 4 ). This shift suggests an increased recognition of Maghrebi states' legitimacy to license privateering and champion navies, which aligns with increases in British-Maghrebi naval conflict and diplomatic negotiation in the period.

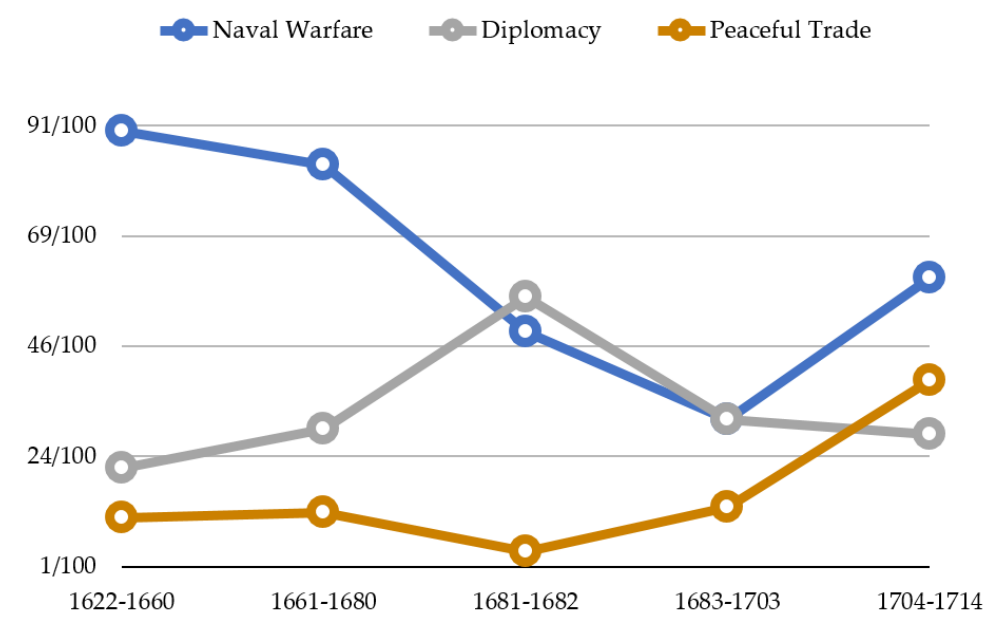

Figure 3. References to maritime combat, diplomacy and trade by period (British and European relations).

16 Other examples include London Gazette, 22-26 September, 3-6 October, 3-7 November 1670, 29 December 1670-1672 January 1671, 30 January-2 February 1671, 23-27 September 1675, 23-27 March 1676, 8-12 November 1677, 25-29 April 1678, 9-12 May, 23-27 June, 3-7 November 1681; Current Intelligence 1-5 November 1681; Impartial Protestant Mercury 4-8 November 1681, 28 February-2 March 1682. 
Table 5. References to maritime combat, diplomacy and trade by period (British and European relations, highlighting period with most references for each topic).

\begin{tabular}{|c|c|c|c|c|}
\hline Topic Category & Time Period & References & $\%$ of Category & $\begin{array}{l}\text { References per } \\
100 \text { Articles }\end{array}$ \\
\hline \multirow{6}{*}{$\begin{array}{l}\text { Maritime Combat } \\
\text { (European against } \\
\text { Maghrebi) }\end{array}$} & $1622-1660$ & 41 & $4.29 \%$ & $39 / 100$ \\
\hline & $1661-1680$ & 409 & $42.78 \%$ & $40 / 100$ \\
\hline & $1681-1682$ & 134 & $14.02 \%$ & $31 / 100$ \\
\hline & 1683-1703 & 120 & $12.55 \%$ & $10 / 100$ \\
\hline & 1704-1714 & 252 & $26.36 \%$ & $42 / 100$ \\
\hline & Total & 956 & $100.00 \%$ & $28 / 100$ \\
\hline \multirow{6}{*}{$\begin{array}{l}\text { Maritime Combat } \\
\text { (Maghrebi against } \\
\text { European) }\end{array}$} & $1622-1660$ & 54 & $5.81 \%$ & $51 / 100$ \\
\hline & $1661-1680$ & 426 & $45.86 \%$ & $42 / 100$ \\
\hline & $1681-1682$ & 79 & $8.50 \%$ & $18 / 100$ \\
\hline & $1683-1703$ & 267 & $28.74 \%$ & $22 / 100$ \\
\hline & 1704-1714 & 103 & $11.09 \%$ & $17 / 100$ \\
\hline & Total & 929 & $100.00 \%$ & $27 / 100$ \\
\hline \multirow{6}{*}{$\begin{array}{l}\text { Maritime Combat } \\
\text { (Total) }\end{array}$} & $1622-1660$ & 95 & $5.04 \%$ & $90 / 100$ \\
\hline & $1661-1680$ & 835 & $44.30 \%$ & $83 / 100$ \\
\hline & $1681-1682$ & 213 & $11.30 \%$ & $49 / 100$ \\
\hline & 1683-1703 & 387 & $20.53 \%$ & $31 / 100$ \\
\hline & $1704-1714$ & 355 & $18.83 \%$ & $60 / 100$ \\
\hline & Total & 1885 & $100.00 \%$ & $56 / 100$ \\
\hline \multirow{6}{*}{$\begin{array}{l}\text { Diplomacy } \\
\text { (Maghrebi with } \\
\text { European) }\end{array}$} & $1622-1660$ & 22 & $1.98 \%$ & $21 / 100$ \\
\hline & $1661-1680$ & 297 & $26.68 \%$ & $29 / 100$ \\
\hline & $1681-1682$ & 242 & $21.74 \%$ & $56 / 100$ \\
\hline & $1683-1703$ & 388 & $34.86 \%$ & $31 / 100$ \\
\hline & 1704-1714 & 164 & $14.73 \%$ & $28 / 100$ \\
\hline & Total & 1113 & $100.00 \%$ & $33 / 100$ \\
\hline \multirow{6}{*}{$\begin{array}{l}\text { Peaceful Trade } \\
\text { (Maghrebi with } \\
\text { European) }\end{array}$} & $1622-1660$ & 12 & $2.23 \%$ & $11 / 100$ \\
\hline & $1661-1680$ & 118 & $21.97 \%$ & $12 / 100$ \\
\hline & $1681-1682$ & 16 & $2.98 \%$ & $4 / 100$ \\
\hline & $1683-1703$ & 161 & $29.98 \%$ & $13 / 100$ \\
\hline & 1704-1714 & 230 & $42.83 \%$ & $39 / 100$ \\
\hline & Total & 537 & $100.00 \%$ & $16 / 100$ \\
\hline
\end{tabular}

\subsection{Ambassadorial Splendour, 1681-1682}

A second watershed occurred both for periodical news publications and for Anglo-Moroccan relations in the early 1680s. In the midst of escalating conflict between Charles II and Parliament over the succession of the Catholic Duke of York, Parliament refused in 1679 to renew the 1662 Licensing Act which had maintained censorship over newspapers, and dozens of new publications stepped into the opening (Handover 1965, pp. 21-23; Childs 1987; Glaisyer 2017, pp. 256-57). As a result, the embassy of Mohammed ben Hadou from the Sultan of Morocco, Ismail ibn Sharif, which even ordinarily would have attracted significant attention (given that the Sultan had relatively recently established the first hegemonic control of Morocco since 1603 and posed a growing threat to English Tangier) received unprecedented publicity. Dozens upon dozens of news articles (as well as the portraits, poems and diaries documented by (Matar 2005, pp. 160-61) ${ }^{17}$ described the minutiæ of Hadou's departure from Morocco, his arrival and public appearances in London, his travels to Newmarket, Oxford and the Royal Society, his negotiations with the King, and his return and reception at home, producing two years of

17 In contrast to the accuracy clearly represented in newspaper sources, Matar's analysis of Elkanah Settle's (admittedly very inaccurate) play The Heir of Morocco leads him to conclude that 'although Bin Haddu was creating much excitement at court and in the city, he was not generating interest in accuracy' (Matar 2005, p. 161). See also (Birchwood and Dimmock 2005, pp. 3-5). 
by far the densest coverage relating to the Maghreb in seventeenth-century news (Table 2). This news coverage, in concordance with Matthew Birchwood and Matthew Dimmock's analysis of Godfrey Kneller's portrait of ben Hadou, displaced 'religious and cultural differences' with 'representations of the ambassador's nobility and "civility", a strategy clearly designed to underscore the parity between the two parties' (Birchwood and Dimmock 2005, pp. 3-5). 'It is discoursed', reported the new True Protestant Mercury (11-14 January 1682):

That the Morocco Ambassador is so well pleased with his Reception, That this morning he waited upon his Majesty, being conducted in his Majesty's Coach to Whitehall; where he presented his Majesty with six most curious Barbary Horses. After which, he invited his Majesty into St. James's Park, to divert himself, with seeing himself and his Attendants shoot, after the manner of their Country, which was performed with such force and exactness, in hitting a small mark at a great distance, That it was a matter of Admiration to his Majesty and all the Spectators, and exceeded the Report of their Expertness.

The following week, ben Hadou had audience with the King, and declared, according to the Loyal Protestant, and True Domestick Intelligence, 'that ... he heartily desir'd a firm Peace with all English, and a free Trade; and particularly, that it might be made for 20 Years, and that the Inhabitants of Tangier might freely Trade 20 miles up in the Country; which His Majesty approving of, His Excellency return'd to his Lodgings' (Loyal Protestant, and True Domestick Intelligence, 19 January 1682). The 'Noble and Generous' ambassador was observed attending bear-baits, horse-baits, military demonstrations, theatre and musical performances, viewing museums and mathematical instruments, dining with and receiving fabulous gifts from English nobles, and even visiting the tomb of Charles I, 'at the sight of which he express'd his abhorrence of the unheard-of Barbarity of those Rebels who Murdered their Royal Sovereign all the time he staid there, which was above half an hour' (London Gazette, 5-9 January, 1-5 June 1682; Loyal Protestant, and True Domestick Intelligence, 12 January, 7 February, 6 April, 8 April 1682; Impartial Protestant Mercury, 10-13 January, 20-24 January, 3-7 March 1682; True Protestant Mercury, 18-22 March 1682; Domestic Intelligence, 26-30 January, 6-10 April 1682). ${ }^{18}$ He was, apparently, quick to elaborately sing the praises of English society:

declaring to several Persons of quality, who have since been to wait on him, That he did not imagine England could have afforded such pleasures, much less the Greatness and Generosity he found at Newmarket and Cambridge; and having spoken much in the Honour of His Majesty, and Favours received from him, he was pleased further to add, That he thought his Royal Highness the completest Prince in the Universe; saying that nothing more remained for him to do, but to buy a quantity of English Goods, and so return to his own Country, there to Blazon as much as in him lyeth, the Greatness of the English Court throughout the World. (London Mercury, 10 April 1682; see also Domestic Intelligence, 26-30 January 1682; Loyal Protestant, and True Domestick Intelligence, 2 February, 4 February 1682)

As a result of this increased coverage, diplomacy for the first time outpaced maritime combat to become the most significant topic in coverage of Maghrebi-European relations, with 56 references per 100 articles, compared to 49 per 100 for maritime combat and just 4 per 100 for peaceful trade (Table 5). A full $21.74 \%$ of all references to British diplomacy with the Maghreb appear in these two years alone (Table 6, Figure 4). The English news was abuzz with the opportunities presented by peace with Maghrebi nations, with wonder and admiration at the dashing ambassador who represented them, and with pride for England's increasing power and dignity reflected in his words.

18 The latter was likely a political move: his master Sultan Ismail ibn Sharif also decried the English regicide, and this sentiment would have played well with Restoration-era audiences. 
Table 6. References to maritime combat, diplomacy and trade by period (British relations only, highlighting period with highest density of references for each topic).

\begin{tabular}{|c|c|c|c|c|c|}
\hline Topic Category & Time Period & References & $\begin{array}{c}\text { \% of British } \\
\text { across All } \\
\text { Periods }\end{array}$ & $\begin{array}{l}\text { References per } \\
100 \text { Articles }\end{array}$ & $\begin{array}{c}\text { \% of all } \\
\text { European in } \\
\text { Each Period }\end{array}$ \\
\hline \multirow{6}{*}{$\begin{array}{l}\text { Maritime } \\
\text { Combat } \\
\text { (British } \\
\text { against } \\
\text { Maghrebi) }\end{array}$} & $1622-1660$ & 2 & $0.71 \%$ & $2 / 100$ & $4.88 \%$ \\
\hline & $1661-1680$ & 184 & $65.71 \%$ & $18 / 100$ & $44.99 \%$ \\
\hline & $1681-1682$ & 65 & $23.21 \%$ & $15 / 100$ & $48.51 \%$ \\
\hline & $1683-1703$ & 22 & $7.86 \%$ & $2 / 100$ & $18.33 \%$ \\
\hline & 1704-1714 & 7 & $2.50 \%$ & $1 / 100$ & $2.78 \%$ \\
\hline & Total & 280 & $100.00 \%$ & $8 / 100$ & $29.29 \%$ \\
\hline \multirow{6}{*}{$\begin{array}{c}\text { Maritime } \\
\text { Combat } \\
\text { (Maghrebi } \\
\text { against British) }\end{array}$} & $1622-1660$ & 6 & $2.91 \%$ & $6 / 100$ & $11.11 \%$ \\
\hline & $1661-1680$ & 127 & $61.65 \%$ & $13 / 100$ & $29.81 \%$ \\
\hline & $1681-1682$ & 33 & $16.02 \%$ & $8 / 100$ & $41.77 \%$ \\
\hline & $1683-1703$ & 22 & $10.68 \%$ & $2 / 100$ & $8.24 \%$ \\
\hline & $1704-1714$ & 18 & $8.74 \%$ & $3 / 100$ & $17.48 \%$ \\
\hline & Total & 206 & $100.00 \%$ & $6 / 100$ & $22.17 \%$ \\
\hline \multirow{6}{*}{$\begin{array}{c}\text { Maritime } \\
\text { Combat (Total) }\end{array}$} & $1622-1660$ & 8 & $1.65 \%$ & $8 / 100$ & $8.42 \%$ \\
\hline & $1661-1680$ & 311 & $63.99 \%$ & $31 / 100$ & $37.25 \%$ \\
\hline & $1681-1682$ & 98 & $20.16 \%$ & $23 / 100$ & $46.01 \%$ \\
\hline & $1683-1703$ & 44 & $9.05 \%$ & $4 / 100$ & $11.37 \%$ \\
\hline & $1704-1714$ & 25 & $5.14 \%$ & $4 / 100$ & $7.04 \%$ \\
\hline & Total & 486 & $100.00 \%$ & $14 / 100$ & $25.78 \%$ \\
\hline \multirow{6}{*}{$\begin{array}{c}\text { Diplomacy } \\
\text { (Maghrebi } \\
\text { with British) }\end{array}$} & $1622-1660$ & 12 & $1.90 \%$ & $11 / 100$ & $54.55 \%$ \\
\hline & $1661-1680$ & 162 & $25.67 \%$ & $16 / 100$ & $54.55 \%$ \\
\hline & $1681-1682$ & 181 & $28.68 \%$ & $42 / 100$ & $74.79 \%$ \\
\hline & $1683-1703$ & 159 & $25.20 \%$ & $13 / 100$ & $40.98 \%$ \\
\hline & 1704-1714 & 117 & $18.54 \%$ & $20 / 100$ & $71.34 \%$ \\
\hline & Total & 631 & $100.00 \%$ & $19 / 100$ & $56.69 \%$ \\
\hline \multirow{6}{*}{$\begin{array}{l}\text { Peaceful Trade } \\
\text { (Maghrebi } \\
\text { with British) }\end{array}$} & $1622-1660$ & 7 & $2.28 \%$ & $7 / 100$ & $58.33 \%$ \\
\hline & $1661-1680$ & 75 & $24.43 \%$ & $7 / 100$ & $63.56 \%$ \\
\hline & $1681-1682$ & 12 & $3.91 \%$ & $3 / 100$ & $75.00 \%$ \\
\hline & $1683-1703$ & 64 & $20.85 \%$ & $5 / 100$ & $39.75 \%$ \\
\hline & $1704-1714$ & 149 & $48.53 \%$ & $25 / 100$ & $64.78 \%$ \\
\hline & Total & 307 & $100.00 \%$ & $9 / 100$ & $57.17 \%$ \\
\hline
\end{tabular}

- Naval Warfare $\quad$ Diplomacy $\quad$ Peaceful Trade

$50 / 100$

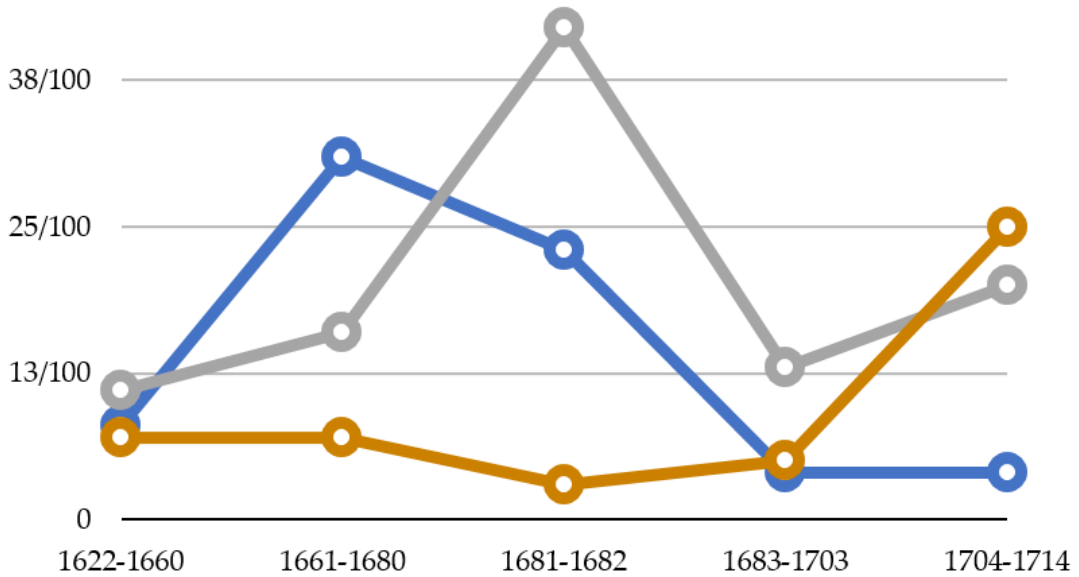

Figure 4. References to maritime combat, diplomacy and trade by period (British relations only). 


\subsection{Governed Peace, $1683-1703$}

Simultaneously, stable relations were reached with the Ottoman Regencies of Algiers and Tripoli. From the conclusion of the long war with Algiers in 1682, peace would reign and passes for safe passage became the order of the day (Stein 2015, pp. 611-12; Heywood 2007, pp. 40-42). According to (Stein 2015, p. 612):

By making the Mediterranean pass the basis for securing English vessels from the threat of Algerian corsairs, the treaty of 1682 established those instruments as an essential and central feature of British navigation. The Admiralty issued 789 Mediterranean passes in 1683, more than it had for the entire 1660s, and 1002 the year following.

Newspapers joyfully celebrated this development, which seemed for the first time to pacify the Maghrebi corsairs. In 1682, the Loyal Protestant, and True Domestick Intelligence reported from Alicante:

The 28th. past arrived here the English Admiral from Algiers, having made his Peace with those Rovers; and besides the old Treaty, he has got several favourable Articles. Amongst the rest, one that the English shall sail 15 months free, without being obliged to show their Pass-ports, and all Foreign Merchandizes and persons in the said Ships shall pass unmolested; and that the Turks of Algiers shall be obliged to strike to all the Kings Ships. The Admiral has presented to the King of Algiers 50 Turkish Slaves, and the Captain of the Tiger, being a Renegade. (Loyal Protestant, and True Domestick Intelligence, 1 June 1682; see also Post Man, 29-31 August 1700)

Censorship over newspapers was reimposed at the accession of James II in 1685, causing a precipitous drop in stories compared to the previous period as the London Gazette once again became the only legal news periodical in England. ${ }^{19}$ This state of affairs continued through the 1688-89 Revolution until Parliament again refused to renew the Licensing Act in 1695 and three major foreign-focused papers appeared (the Post Boy, the Post Man, and the Flying Post), significantly boosting overall coverage of the Maghreb (Glaisyer 2017, pp. 256-57). Such stories as were published before 1695 indicate that passes continued to hold their place. In 1689, the Gazette published the following royal proclamation: 'These are to give Notice, That the Mediterranean Passes required by the Articles of Peace with Argier, Tunis and Tripoli, are now setled by His Majesty's Order in Council, and will be granted accordingly; to all Merchant Ships trading into those Parts' (London Gazette, 28-31 October 1689). From its inception, argues (Stein 2015, p. 624), 'North African corsairs and governments approached the pass system in accordance with the established practices of the corso and their understanding of their treaties with Britain', allowing British ships to pass by freely. Trade with the Maghreb is reported as if unexceptional, alongside reports of ships arriving from America and Europe: 'Last Saturday came into Cows Road two Dutch Ships, one from Salley in Barbary, laden with Hides, Copperas and Almonds, the other from Cadiz, bound home with Oil' (Post Boy, 15-17 June 1697; see also Flying Post, 1-3 October, 22-24 December 1702; Post Man, 22-24 December 1702, 24-26 June 1703; Daily Courant, 25 January 1703). Though the Moroccan Sultan refused to ratify his Ambassadors' treaty negotiated in 1682, successfully reconquered Tangier in 1684, and allowed the corsairs at Salé to again fitfully attack English shipping, Moroccan naval strength (and Maghrebi corsair strength as a whole) was on the decline (Matar 2014, pp. 128, 132-41; Matar 2010; Erzini 2002, pp. 2-5; Chaney 2015).

The shift towards peace can also be observed on a statistical level, as references to British-Maghrebi maritime combat dropped from 31 per 100 articles in 1661-1680, to 23 in 1681-1682, to just 4 in 1683-1703 and 1704-1714, and references to both diplomacy and peaceful trade increased significantly

19 This drop may also have been to do with the increased level of peaceful interaction-(Ghobrial 2013, p. 27) has noted that 'news about the Ottomans peaked at specific moments of military confrontation' like the battle of Lepanto (1571), the conquest of Candia (1669) and the siege of Vienna (1683), and declined in periods of relative peace. 
(Table 6). Perhaps counter-intuitively, given the decline in Maghrebi maritime power relative to Britain, descriptions of Maghrebi ships as illegitimate pirates or rovers returned as the most common categorisation in this period, overtaking legitimate or naval terms (Tables 3 and 4). This relative shift can be largely explained by the significant decrease in British conflict with the regencies, reducing the reporting of Maghrebi ships from states the English recognised (just $9.05 \%$ of all references to British-Maghrebi maritime combat appear in this period, Table 6), and the resurgence of Moroccan corsairing out of Salé in this period. These latter corsairs were usually known as 'rovers' in this period and were considered illegitimate but not a significant threat ('rover' overtook 'pirate' in this period to comprise a significant majority of illegitimate terms in 1683-1703 and 1704-1714, see Tables 3 and 4). Overall, in this period, Britain increasingly became a friend to the Maghreb, and a power in the Mediterranean - both in reality and in the papers.

\subsection{Cooperation, Commodities, Comedy, 1704-1714}

During the War of the Spanish Succession (1701-1714), and especially after the British capture of Gibraltar (1704) and Minorca (1708), military, naval and economic cooperation with the Maghreb increased significantly, even as Maghrebi naval power declined (Panzac 2005, p. 42). England and Morocco rekindled their diplomatic relations at the turn of the seventeenth century, and by 1705, Gibraltar was completely dependent for food and many raw materials on Moroccan imports, and England and France fought over the right to purchase grain from the Ottoman Regencies (Brown 2008; Matar 2013; Matar 2008, pp. 290-93). The Post Man printed in 1705 a letter from Madrid, which reported:

'Tis discoursed here that the English have concluded a new Alliance with the Emperor of Morocco, who is to furnish them with Horses, \&c. and the Alcaide Aly [the provincial governor near Tangier] was ordered to supply the Garrison of Gibraltar with Provisions. They add, that the Prince of Darmstat [a German ally of Britain] sent an Engineer to Compliment the Alcaide, and view the Works of the Moors against Ceuta, which he did, and ordered some Batteries to be chang'd. (Post Man, 15-17 March 1705)

European relations with Morocco were not uncontroversial abroad-in 1705, a propaganda war of sorts appeared in the English newspapers as supporters of the French and supporters of the Austrian claimant to the Spanish throne in the War of the Spanish Succession both attempted to smear one another's reputation for forming alliances with Morocco and the Ottoman Empire-but the move towards positive relations with the Maghreb was an irresistible tide (Post Man, 15-17 March, 26-28 April, 8-10 May 1705; London Post, 2 April 1705). References to British-Maghrebi trade dramatically increased to 25 per 100 articles in 1704-1714, as British merchants increased trade to and from the Maghreb, and newspapers began to aggressively advertise the exotic goods they brought home with them: 'On Friday ... will be exposed to sale, at the Marine Coffee-house in Birchin-lane ... the Cargo of the Unity lately arrived from Barbary; consisting of New, sweet and bitter Almonds, Aniseeds, Gum Sandrack, Gum Arabick, Bees Wax, \&c. and several other Druggs' (Post Man, 11-14 September 1708; see also Post Boy, 8-10 July, 10-13 July 1714; Post Man, 16-19 August, 4-6 December 1707; Daily Courant 5 December, 8 December 1707, 26 July 1708, 1 February, 2 February, 4 March, 6 March, 14 March, 10 July, 17 July 1710, 11 January, 28 April, 2 September 1712, 1 December 1713, 13 March, 5 June, 8 June, 3 July, 6 July, 8 July, 10 July, 13 July 1714). In contrast, the coverage of maritime combat remained high for non-British European combatants, even as references to peaceful trade also reached their highest concentration in 1704-1714 (Table 5). When Ambassadors periodically arrived from all four Maghrebi countries, they were both lavishly treated and lavishly reported, more frequently than any other period except 1681-1682 (Table 6) and, most distinctively to this period, employed as an enticement to attend theatrical performances: 'For the Entertainment of Don Venturo Zary, the Emperour of Morocco's Minister and Elhauge Guzman, the Royal Messenger, (from the said Emperour Muley Ismael, to her Majesty) with their Attendants in their several Habits. Being the first time of their Appearance in 
publick... At the Queen's Theatre in the Hay-Market, this present Thursday, being the 4th of May, will be Reviv'd a Play, called, King Henry the Fourth, with the Humours of Sir John Falstaff' (Daily Courant, 4 May 1710; see also Daily Courant, 2 May, 13 May, 15 May, 20 May, 21 May, 16 August, 6 November 1706, 3 July 1707, 30 May, 31 May 1709, 3 May 1710, 20 December 1711; Post Boy, 29 April-2 May 1710). Peace with pirates, at least from the perspective of the newspapers, had finally been achieved, and Maghrebis were safe enough to join at the theatre.

\section{Discussion and Conclusions}

In sum, the news published about Maghrebi maritime combat, diplomacy and trade was surprisingly detailed and informative about the diverse, reciprocal and negotiated relations between Maghrebi states, Europe and Britain. These stories presented to their audiences Maghrebi corsairs who were able to inflict serious damage on their enemies, but who were increasingly inclined over this period to form stable, prosperous and mutually beneficial peaces with their friends, and particularly with Britain. These were not simply the brutal, unmanageable Barbary pirates of stage, story, and song, but instead real, complex, developing, dangerous yet reasonable nations in their own right.

This conclusion prompts two significant questions: first, why and how did this information find its way into newspapers, rather than simply remaining in the diplomatic and naval archives? At one level, there is a simple answer: newspapers were based on the latest letters and printed accounts from abroad, and as such were more likely to record actual events. They also produced comparatively short accounts relative to captivity narratives, books and pamphlets, usually leaving little space for polemical reflection (Handover 1965, p. 26). ${ }^{20}$ However, foreign letters always went through a process of selection and editing before being printed; so the question remains of how and why these particular stories, presenting this particular spin on Maghrebi warfare, diplomacy and trade, were deemed appropriate for public consumption (Sutherland 1986, pp. 123-45).

On the most basic level, Maghrebi subjects were of interest, like news of warfare, diplomacy and trade in other parts of Europe and the Mediterranean, since they had a profound effect on England's position in the world, its government policy, and the profitability of mercantile trade in the Mediterranean: merchants needed to know where was safe to send their goods and money. Maghrebi stories also offered a marketable dose of exoticism and excitement, of naval battles, religion, and political intrigue, that likely made them popular reading. They could also, as we have seen during the War of the Spanish Succession, be politically controversial, and play into larger stories of intra-European relations (see Cutter 2018, pp. 67-68; Raymond 2011a, p. 10; Raymond 1998, pp. 126-28; Ellinghausen 2018, p. 130; Guasco 2014, pp. 125-27; Handover 1965, pp. 11-12, 21-22; Maclean 2007, p. 205). For privately-owned papers, which make up the majority of my corpus (Table 7), this is perhaps sufficient reason to explain why Maghrebi stories were printed: their readers both wanted and needed to know.

However, over $46 \%$ of my news corpus comes from government sources (mostly the London Gazette, with a small percentage from its late-Commonwealth/early-Restoration antecedents, see Table 7). Published from the office of the Secretaries of State, these papers functioned to inform, distract and influence British readers, who looked to the government publications as a common point of reference on current events, for confirmation of oral reports, to identify the government's official line on particular issues, and as a journal of record for later consultation (Glaisyer 2017, p. 263; Handover 1965, pp. 35-36). By a comparison to foreign powers of the time, it is perhaps surprising that the British government should have publicised its increasingly positive relations with the Maghrebi states; even less that it should emphasise their positivity. Phillip McCluskey has argued that Louis XIV of France sought in the 1660s to placate anti-Islamic public opinion, and distract attention from his

20 (Ghobrial 2013, pp. 122-58) has documented in great detail how stories of the deposition of the Ottoman Sultan Mehmed IV made their way from local events through English diplomats to English newspapers and English readers. 
policy of treaty negotiation and peace formation with the Maghrebi states, by loudly building up his navy and invading Algerian Jijel in 1664. This, according to McCluskey, allowed 'Louis XIV to pose as a champion of Christianity while pursuing intrinsically commercial and political objectives'. It was not until the later seventeenth century brought the adoption of turquerie, and with it 'a wider demystification of the Muslim world in general', that the government could be more transparent about its goals (McCluskey 2009, pp. 4-9). Likewise, Virginia Lunsford has documented a strongly adversarial tone in seventeenth-century Dutch news media about Maghrebi corsairs, both following and shaping public opinion. She concludes that corsairs 'were feared, loathed, and morally condemned by the citizens of the United Provinces is indisputably true-vanquishing them was a laudatory and even patriotic achievement' (Lunsford 2005, pp. 74-76, 79-85). If seventeenth-century British popular attitudes were as hostile as we have been told, then the government newspapers would surely have obscured the truth. Yet, by my assessment, the opposite is true.

Table 7. Articles relating to the Maghreb by publication.

\begin{tabular}{lcc}
\hline Publication & Articles & \% of Total Articles \\
\hline Oxford/London Gazette (1665-1714+) & 1445 & $42.69 \%$ \\
Post Boy (1695-1714+) & 282 & $8.33 \%$ \\
Daily Courant (1702-1714+) & 260 & $7.68 \%$ \\
Flying Post (1695-1714+) & 229 & $6.77 \%$ \\
Post Man (1695-1714+) & 196 & $5.79 \%$ \\
London Post (1699-1705) & 98 & $2.90 \%$ \\
Domestic Intelligence (1679-1681) & 74 & $2.19 \%$ \\
True Protestant Mercury (1680-1682) & 70 & $2.07 \%$ \\
Loyal Protestant and True Domestick Intelligence (1681-1683) & 60 & $1.77 \%$ \\
British Mercury (1710-1714+) & 54 & $1.60 \%$ \\
English Post (1700-1709) & 47 & $1.39 \%$ \\
Evening Post (1710-1714+) & 38 & $1.12 \%$ \\
Total: Top 12 (each over 1\% of total) & 2853 & $84.28 \%$ \\
Total: Remaining 95 (each less than 1\% of total) & 532 & $15.72 \%$ \\
Total: Government Papers & 1574 & $46.50 \%$ \\
Total: Non-Government Papers & 1811 & $53.50 \%$ \\
\hline
\end{tabular}

One possible explanation for this is suggested in Nabil Matar's examination of the role Maghrebi captivity played in the English Civil War. In 1645, faced with mounting captive numbers, and significant popular petitions and protests led by the wives and mothers of captives, 'Parliament sought to show that the money it had been collecting for years in customs would serve the intended purpose of ransoming Barbary captives' by sending a delegation to Algiers, and then printing an extensive one-off account of the proceedings and (crucially) the names and details of all 242 redeemed captives. Parliament followed this with two letters sent from captives in Algiers that explicitly praised their activities. According to Matar, 'Where the King had failed, now Parliament could show, both nationally and internationally, that it was succeeding' (Matar 2001a, pp. 251-53). The laudatory potential of government media is borne out by a report published in the (non-government) Faithful Scout in 1652, which is worth quoting in full:

The Parliament took into consideration, the sad and deplorable condition of many hundreds of poor Christians, which have long lain under the persecution of Turkish Tyranny; and after some Debate thereupon came to this glorious Result, viz. That the Speaker be forthwith dispatched to Argier in Turkey (not the Speaker of the Hous, mistake me not; but the good ship called the Speaker) with the sum of thirty thousand pounds, to redeem poor English Captives from exile and cruell slavery: Which ship lies now at Tilbury-Hope, under the Conduct and Command of Captain Thorowgood, who hath 27 Chests of Silver aboard her, and is ready to weigh Anchor, and hoyst sayl, for the performance of this gallant Enterprise. A prosperous Gale attend his Motion; and a Christian Vote, and Blessing, be present, in all 
his Debates and Consultations; for, doubtless, 'tis a Sacrifice pleasing both to God and Man, and plainly denotes unto the people of England, that our Magistrates had rather buy home exiles, then make more. (Faithful Scout, 23-30 January 1652)

Though Matar has argued elsewhere that the 'explosive and politically destabilising' issue of Maghrebi piracy and captivity had just a decade or two later in the reign of Charles II been 'relegated to insignificance' in government policy towards public discourse, the news stories printed in the Gazette and its government-owned predecessors provide clear evidence of a continued political program of emphasising positive engagement with the Maghrebi states (Matar 2005, p. 152). ${ }^{21}$ In a system of responsible government shaped by the Wars of the Three Kingdoms and later by the Revolution of 1688-1689, perhaps it is less surprising that British governments should have used media coverage of the Maghreb to emphasise their diplomatic and naval triumphs, assuage public anxiety, and encourage trade, rather than to reinforce or stoke existing enmities against the Maghreb. ${ }^{22}$

A second important question is, who read these accounts, and what effect did they have? It is often noted that evidence for readership of early modern periodicals is sparse, given their cheapness, ephemerality and rapid turnover (Berry 2000, p. 21). ${ }^{23}$ News about Maghrebi maritime combat, diplomacy and trade certainly reached the public in Britain, particularly at the Royal Exchange in London (according to (Ghobrial 2013, p. 42), 'when it came to obtaining information about the Mediterranean world, few places could compare in the seventeenth century to the Royal Exchange'), but the extent to which this news was sourced from periodical news publications is unclear. Brian Cowan has documented how a number of coffeehouse-keepers in London were arrested for spreading leaked information about a planned British attack against Algiers, and were warned not to distribute it further or take in newspapers for their patrons to read, for fear the news would eventually reach the Algerians (Cowan 2004, pp. 41-42). Samuel Pepys famously called the London (then Oxford) Gazette 'very pretty, full of newes and no folly in it', but at no point in his diary does he mention the news he heard in public about the Maghreb came from papers, rather than other sources (Handover 1965, p. 12). He wrote in January 1662, 'I am troubled to hear that the Turks do take more and more of our ships in the Straights'; in November 1662, 'Newes that Sir J[ohn] Lawson hath made up a peace now with Tunis and Tripoli, as well as Argiers, by which he will come home very highly honoured'; and in November 1664, 'so to London by coach and to the Coffee-house, where certain news of our peace made by Captain Allen with Argier, which is good news' (Pepys 1660-1669). ${ }^{24}$ Each of these, as noted above, was reported in the government newspapers, but was significant enough that the information likely circulated through multiple channels, so it is difficult to connect them directly. Similarly, Puritan minister Roger Morrice recorded in his Entring Book, a rich record of English political society from 1677-1691, several pieces of news about the Maghreb, without indicating his sources (aside from the ambiguous use of 'letters'). He wrote in March 1678, 'The Algerines have taken about 14 of our Merchant ships in the Medeteranean'; in October 1682, 'The Pirates of Saley are credibly reported to have taken 6 or 7 of our Shipps of late'; and in June 1687, 'Many Letters came to the [Royal] Exchange on Monday last, as there had done one to the Court the last weeke that told us the Algeires had taken six Dutch Ships upon their Coasts, very neare their Ports, the like passage has hardly sounded in our ears and the discourse and alarme upon the Change makes it full as great as it is' (Morrice 2009, pp. 2:55, 2:327, 4:86). In 1689,

21 (Matar 2005, pp. 153, 158) does recognise isolated Restoration publications as serving a propagandistic purpose in support of defending Tangier against the Moroccans (one government and several private), as well as one printed account heralding a naval victory against Tripoli, but in neither case do the writers present a positive view of the Maghrebi states or their relationships with Britain.

22 (Parker 2004, p. 101) asks this question in relation to the official, stand-alone publication of Articles of Peace in the early Restoration period, but does not venture to answer it.

23 (Ghobrial 2013, p. 37) has noted that Sir William Trumbull collected copies of the London Gazette (as well as French equivalents and numerous printed books and pamphlets) before, during and after his tenure as British Ambassador to the Ottoman Empire, but does not comment on the content or effect of this material.

24 Pepys 1660-1669, 19 January 1662 (available at: https://www.pepysdiary.com/diary/1662/01/19/), 22 November 1662 (available at https://www.pepysdiary.com/diary/1662/11/22/), 28 November 1664 (https://www.pepysdiary.com/diary/1664/11/28/). 
Morrice became concerned with reports about French negotiations with Algiers: 'The King of France is reported to have taken Gibletower (Gaibralter) a great passage from the Medeterenian, but I think its not true[.] He has also hired all the usefull Vessells the Algerines can furnish him with'; then 'The Algerines have made a Peace with France, who is to give them Shelter in any of the Ports belonging to his Dominions, to furnish them with Commanders, and Engineers to manage their War against Spain, and also to furnish them with Shipps and recruits upon all occasions'; and 'The French King offereth not only very honourable and advantageous conditions to the Algerians for a Peace with them, but seemes to Condescend very low' (Morrice 2009, pp. 5:89, 325, 327). These same negotiations appear in the London Gazette, which reported from Paris in October 1689, 'It is confirmed that the French have made, or rather bought, a Peace of the Algierines, and that upon dishonourable Terms too, which are therefore not made publick here', and in December, 'By a Vessel come lately from Argiers we have the Confirmation of the French having made a Peace with that Government; but how honourable the Terms of it are for the Crown of France, will appear by an Abstract of the Articles, which follows' (London Gazette, 21-24 October, 16-19 December 1689). The unclarity of the sources of news heard in the Royal Exchange and coffeehouses by men like Pepys and Morrice makes it difficult to draw conclusions about reception, beyond what Helen Berry calls the 'implied readers' suggested by the content and structure of the papers (Berry 2000, p. 21). However, it is reasonable to argue both from the content and the kind of material recorded by Pepys and Morrice that Maghrebi maritime combat and diplomacy were of significant interest to power-brokers in London society.

Similarly little can be conclusively said about how this coverage affected Anglophone views of the Maghreb and its people. Adam Fox has argued that, particularly after the Restoration, 'it is clear that many of people's attitudes and opinions were conditioned or provoked by what they knew from printed sources' (Fox 2002, pp. 396, 400); and, more specifically, Mark Hanna has shown that the 'abundance of information on sea marauding in the metropole's public prints' around the turn of the eighteenth century, often one or more stories a week, meant that 'attacks in the Indian Ocean were not so unimaginably distant', and that 'a London readership could create a rudimentary mental map of interconnected events from the Indian Ocean to the West Indies to New England and back to Newgate prison in London' as well as developing clear understandings of the legality and illegality of different forms of piracy and privateering (Hanna 2015, p. 198). The application of these general statements to Maghrebi material requires further research, but the similar density of articles (a consistent average of over 50 articles per year, or one per week in 1661-1680, 1683-1703, and 1704-1714, Table 1) suggests that knowledge of Maghrebi affairs was equally, if not more, significant than that of Hanna's pirates.

Periodical news coverage may have had certain cultural impacts on other sources about the Maghreb. Matar has repeatedly noted that as the seventeenth century wore on, English-language literary and dramatic representations of Muslims, including captivity narratives, declined dramatically, to the extent that during the period 1702-1713, when Muslims of the Maghreb were 'partly responsible for Britain's rise to supremacy', 'there was no significant imagining of the Islamic Mediterranean in English thought' (Matar 2013, pp. 21-22; Matar 2005, p. 161). ${ }^{25}$ Yet English newspaper readers in this period could find at least one article every week describing affairs of the Maghreb (Table 1). Perhaps, following a general shift in English popular culture towards 'factual' accounts of life abroad, news filled the space left by declining representations in captivity narratives and theatre; or, conversely, influenced British culture away from fantastical and terrifying depictions of the Maghreb (Maclean 2019, p. 76; Leask 2019, p. 93). Such English-language captivity narratives as were published after the Restoration, such as Thomas Smith's William Okeley's Eben-ezer; or, A Small Monument of Great Mercy (1675), Francis Brooks' Barbarian Cruelty (1693), and Joseph Pitts' A True and Faithful Account of the Religion and Manners of the Mohammetans (1704) are significantly longer, more informative, and more reflective than the often briefer, news-style narratives of earlier periods (Matar 2001b, pp. 35, 39; Auchterlonie 2012,

25 (Birchwood 2007) ends where it does for similar reasons. See also (Birchwood 2005, p. 74). 
p. 4). Given that accounts of naval battles, captive redemptions, and even, on at least one occasion, a letter of news purporting to come directly 'from a Slave in Salley' (London Post, 10-13 November 1699) appeared in the newspapers, perhaps captivity writers felt compelled to alter their styles. This could have been because the market for short accounts was being drawn away; it could also have been a reaction against newspapers' presentation of increasingly positive interactions with the Maghreb. Nabil Matar, for example, has argued that Okeley's captivity narrative, which describes events taking place in 1639-1644, was composed and published in 1675 precisely because captivity had become a less important issue in both politics and the society at large, prompting the author to recall his story and thereby remind his readers of the true threat Maghrebi maritime combat and captivity posed (Matar 2005 , p. 152). While it is unlikely that captivity narratives would have captured precisely the same market as periodical news, the correlation of these trends is telling.

These cultural effects must also be considered in light of all the other sources available to British audiences to learn about the Maghreb. The neutral, and at times even positive, coverage found in these periodical news sources must be integrated within a cultural milieu in which the weight of public opinion was still suspicious, or outright negative, towards the "Turks" and "Moors" of "Barbary" despite the periodic goodwill generated by such events as the 1681-82 embassy. Why this should have happened remains unclear. Did the merchants and officials who composed and disproportionately consumed these publications operate according to significantly different terms of reference than the wider public? Were public audiences more influenced by longer or more popular works than ephemeral periodicals, despite the wide reach and relatively dense and consistent flow of information they offered?

For the purposes of this article, at the very least it can be shown that Restoration readers, particularly those in London, had available to them a great deal more information about Maghrebi warfare, diplomacy and trade with Britain and Europe than has previously been recognised in scholarship, and that it is likely this information was widely read and influenced to some extent popular perceptions and literary presentations of the Maghreb in later seventeenth-century Britain. In addition to the future research required into the cultural impact of news coverage on British views and representations of the Maghreb, fruitful work could be done into the mechanisms by which news of the Maghreb reached Britain, and in particular the special role of British residents in the Maghreb in observing, recording and transmitting that news to a British public.

Funding: This research was supported by an Australian Government Research Training Scholarship, as well as by travel funding from the University of Melbourne's Graduate Research Travel in Arts Scheme and Arts Graduate Research International Grant, and a bursary from the University of Kent's MEMS Fest.

Acknowledgments: Thanks to Claire Jowitt and Manushag Powell for editing this special issue; to the participants in MEMS Fest (Canterbury), Medievalism Transformed (Bangor), and Problem of Piracy (Glasgow) in June 2019 for providing useful feedback on an early version of this paper; to the three anonymous reviewers for their helpful suggestions; to my supervisors Richard Pennell and Una McIlvenna for their support, mentorship and guidance; and to Belinda Cutter, for everything.

Conflicts of Interest: The author declares no conflict of interest.

\section{References}

Akihito, Kudo, and Ota Atsushi. 2018. Privateers in the Early-Modern Mediterranean: Violence, Diplomacy and Commerce in the Maghreb, c. 1600-1830. In In the Name of the Battle Against Piracy: Ideas and Practices in State Monopoly of Maritime Violence in Europe and Asia in the Period of Transition. Edited by Ota Atsushi. Leiden: Brill, pp. 19-42.

Andrea, Bernadette, and Linda McJannet, eds. 2011. Early Modern England and Islamic Worlds. Houndmills: Palgrave Macmillan.

Auchterlonie, Paul. 2012. Encountering Islam: Joseph Pitts: An English Slave in 17th-Century Algiers and Mecca. London: Arabian Publishing.

Backman, Clifford R. 2014. Piracy. In A Companion to Mediterranean History. Edited by Peregrine Horden and Sharon Kinoshita. Chichester: Wiley-Blackwell, pp. 170-83. 
Bak, Greg. 2000. English Representations of Islam at the Turn of the Century: Islam Imagined and Experienced, 1575-1625. Ph.D. dissertation, Dalhousie University, Halifax, NS, Canada.

Barbano, Matteo. 2018. A lucrative, dangerous business: le consulat anglais à Alger, Tunis et Tripoli dans la deuxième moitié du XVIIe siècle. In De L'utilité Commerciale des Consuls. L'institution Consulaire et les Marchands dans le Monde Méditerranéen (XVIIe-XXe Siècle). Edited by Arnaud Bartolomei, Guillaume Calafat, Mathieu Grenet and Jörg Ulbert. Rome: École Française de Rome, pp. 253-64.

Bartels, Emily C. 2008. Speaking of the Moor from Alcazar to Othello. Philadelphia: University of Pennsylvania Press. Beijit, Karim. 2015. English Colonial Texts on Tangier, 1661-1684: Imperialism and the Politics of Resistance. Farnham: Ashgate.

Ben Rejeb, Lofti. 2012. "The General Belief of the World": Barbary as genre and discourse in Mediterranean history. European Review of History: Revue européenne d'histoire 19: 15-31. [CrossRef]

Berry, Helen. 2000. An Early Coffee House Periodical and its Readers: The Athenian Mercury, 1691-1697. London Journal 25: 14-33. [CrossRef]

Birchwood, Matthew, and Matthew Dimmock. 2005. Introduction. In Cultural Encounters Between East and West, 1453-1699. Edited by Matthew Birchwood and Matthew Dimmock. Cambridge: Cambridge Scholars Press, pp. 1-12.

Birchwood, Matthew. 2005. News from Vienna: Titus Oates and the True Protestant Turk. In Cultural Encounters Between East and West, 1453-1699. Edited by Matthew Birchwood and Matthew Dimmock. Cambridge: Cambridge Scholars Press, pp. 64-76.

Birchwood, Matthew. 2007. Staging Islam in England: Drama and Culture, 1640-1685. Cambridge: D.S. Brewer.

Black, Jeremy. 2001. British Diplomats and Diplomacy 1688-1800. Exeter: University of Exeter Press.

Brown, J.A.O.C. 2008. Anglo-Moroccan Relations and the Embassy of Ahmad Qardanash, 1706-1708. Historical Journal 51: 599-620. [CrossRef]

Burton, Jonathan. 2005. Traffic and Turning: Islam and English Drama, 1579-1624. Newark: University of Delaware Press.

Calafat, Guillaume. 2011. Ottoman North Africa and ius publicus europaeum: The case of the treaties of peace and trade (1600-1750). In War, Trade and Neutrality: Europe and the Mediterranean in the Seventeenth and Eighteenth Centuries. Edited by Antonella Alimento. Milan: Franco Angelli, pp. 171-86.

Chaney, Eric. 2015. Measuring the military decline of the Western Islamic World: Evidence from Barbary ransoms. Explorations in Economic History 58: 107-24. [CrossRef]

Childs, John. 1987. The Sales of Government Gazettes during the Exclusion Crisis, 1678-81. English Historical Review 102: 103-6. [CrossRef]

Çirakman, Asli. 2005. From the "Terror of the World" to the "Sick Man of Europe": European Images of Ottoman Empire and Society from the Sixteenth Century to the Nineteenth. New York: Peter Lang.

Cowan, Brian. 2004. The Rise of the Coffeehouse Reconsidered. Historical Journal 47: 21-46. [CrossRef]

Cutter, Nat. 2018. Turks, Moors, Deys and Kingdoms: North African Diversity in English News before 1700. Melbourne Historical Journal 46: 61-84.

Davis, Robert C. 2009. Christian Slaves, Muslim Masters: Tales of Christian-Muslim Slavery in the Early-Modern Mediterranean. Santa Barbara: Praeger.

Dimmock, Matthew. 2016. New Turkes: Dramatising Islam and the Ottomans in Early Modern England. London: Routledge.

Ellinghausen, Laurie. 2018. Pirates, Traitors, and Apostates: Renegade Identities in Early Modern English Writing. Toronto: University of Toronto Press.

Erzini, Nadia. 2002. Moroccan-British Diplomatic and Commercial Relations in the Early 18th Century: The Abortive Embassy to Meknes in 1718. (Durham Middle East Paper 70). Durham: University of Durham Press.

Fox, Adam. 2002. Oral and Literate Culture in England 1500-1700. Oxford: Oxford University Press.

Ghobrial, John-Paul. 2013. The Whispers of Cities: Information Flows in Istanbul, London, and Paris in the Age of William Trumbull. Oxford: Oxford University Press.

Glaisyer, Natasha. 2017. The Most Universal Intelligencers: The circulation of the London Gazette in the 1690s. Media History 23: 256-80. [CrossRef]

Guasco, Michael. 2014. Slaves and Englishmen: Human Bondage in the Early Modern Atlantic World. Philadelphia: University of Pennsylvania Press.

Handover, P. M. 1965. A History of the London Gazette 1665-1965. London: HM Stationery Office. 
Hanna, Mark G. 2015. Pirate Nests and the Rise of the British Empire, 1570-1740. Chapel Hill: University of North Carolina Press.

Helgason, Porsteinn. 2018. The Corsairs' Longest Voyage: The Turkish Raid in Iceland 1627. Leiden: Brill.

Hershenzon, Daniel. 2018. Slavery, Communication, and Commerce in Early Modern Spain and the Mediterranean. Philadelphia: University of Pennsylvania Press.

Heywood, Colin. 2007. Ideology and the profit motive in the Algerine Corso: The strange case of the Isabella of Kirkcaldy. In Anglo-Saxons in the Mediterranean: Commerce, Politics and Ideas (XVII-XX Centuries). Edited by C. Vassallo and M. D'Angelo. Malta: Malta University Press, pp. 17-42.

Hunter, F. Robert. 1999. Rethinking Europe's Conquest of North Africa and the Middle East: The opening of the Maghreb, 1660-1814. Journal of North African Studies 4: 1-26. [CrossRef]

Hwang Degenhardt, Jane. 2010. Islamic Conversion and Christian Resistance on the Early Modern Stage. Edinburgh: Edinburgh University Press.

Kaiser, Wolfgang, and Guillaume Calafat. 2014. Violence, Protection and Commerce: Corsairing and ars piratica in the Early Modern Mediterranean. In Persistent Piracy: Maritime Violence and State-Formation in Global Historical Perspective. Edited by Stefan Eklöf Amirell and Leos Müller. Houndmills: Palgrave Macmillan, pp. 69-92.

Klarer, Mario, ed. 2019. Piracy and Captivity in the Mediterranean, 1550-1810. London: Routledge.

Leask, Nigel. 2019. Eighteenth-Century Travel Writing. In The Cambridge History of Travel Writing. Edited by Nandini Das and Tim Young. Cambridge: Cambridge University Press, pp. 93-107.

Lofkrantz, Jennifer, and Olatunji Ojo, eds. 2016. Ransoming, Captivity E Piracy in Africa and the Mediterranean. Trenton: Africa World Press.

Lunsford, Virginia West. 2005. Piracy and Privateering in the Golden Age Netherlands. Houndmills: Palgrave Macmillan.

Maclean, Gerald. 1995. Culture and Society in the Stuart Restoration. Cambridge: Cambridge University Press.

Maclean, Gerald. 2007. Looking East: English Writing and the Ottoman Empire before 1800. Houndmills: Palgrave.

Maclean, Gerald. 2019. Early Modern Travel Writing (1): Print and Early Modern European Travel Writing. In The Cambridge History of Travel Writing. Edited by Nandini Das and Tim Young. Cambridge: Cambridge University Press, pp. 62-76.

Matar, Nabil. 1999. Turks, Moors, and Englishmen in the Age of Discovery. New York: Columbia University Press.

Matar, Nabil. 2001a. The Barbary Corsairs, King Charles I and the Civil War. Seventeenth Century 16: $239-58$. [CrossRef]

Matar, Nabil. 2001b. Introduction: England and Mediterranean Captivity, 1577-1704. In Piracy, Slavery, and Redemption. Edited by Daniel J. Vitkus. New York: Columbia University Press, pp. 1-54.

Matar, Nabil. 2003. The Last Moors: Maghāriba in Early Eighteenth-Century Britain. Journal of Islamic Studies 14: 37-58. [CrossRef] [PubMed]

Matar, Nabil. 2005. Britain and Barbary, 1589-1689. Gainesville: University Press of Florida.

Matar, Nabil. 2008. Islam in Britain, 1689-1750. Journal of British Studies 47: 284-300. [CrossRef]

Matar, Nabil. 2010. The Maghariba and the Sea: Maritime Decline in North Africa in the Early Modern Period. In Trade and Cultural Exchange in the Early Modern Mediterranean: Braudel's Maritime Legacy. Edited by Maria Fusaro, Colin Heywood and Mohamed-Salah Omri. London: I.B. Tauris, pp. 117-39.

Matar, Nabil. 2013. Morocco and Britain during the War of the Spanish Succession. Hespéris-Tamuda 48: 9-23.

Matar, Nabil. 2014. British Captives from the Mediterranean to the Atlantic, 1563-1760. Leiden: Brill.

McCluskey, Phillip. 2009. Commerce before Crusade? France, The Ottoman Empire and the Barbary Pirates (1661-1669). French History 23: 1-21. [CrossRef]

McJannet, Linda. 2006. The Sultan Speaks: Dialogue in English Plays and Histories about the Ottoman Empire. Houndmills: Palgrave Macmillan.

Meyers, Allan R. 1977. Beeswax and Politics in Morocco, 1697-1701. Bee World 58: 153-60. [CrossRef]

Morrice, Roger. 2009. The Entring Book of Roger Morrice [1677-1691]. Edited by Mark Goldie. Woodbridge: Boydell and Brewer.

Murray, Theresa Denise. 2006. From Baltimore to Barbary: The 1631 Sack of Baltimore. History Ireland 14: 14-18.

Nelson, Carolyn, and Matthew Seccombe. 1987. British Newspapers and Periodicals 1641-1700. New York: Modern Language Association of America.

Panzac, Daniel. 2005. Barbary Corsairs: The End of a Legend 1800-1820. Translated by Victoria Hobson, and John E. Hawkes. Leiden: Brill. 
Parker, Kenneth. 2004. Reading Barbary in Early Modern England, 1550-1685. Seventeenth Century 19: 87-114. [CrossRef]

Parry, Clive, ed. 1969-1980. Consolidated Treaty Series. New York: Oceana Publications.

Pepys, Samuel. 1660-1669. Diary. Available online: https://www.pepysdiary.com (accessed on 13 November 2019). Raymond, Joad. 1998. The newspaper, public opinion, and the public sphere in the seventeenth century. Prose Studies 21: 109-36. [CrossRef]

Raymond, Joad. 2011a. Introduction: The Origins of Popular Print Culture. In The Oxford History of Popular Print Culture, Volume 1: Cheap Print in Britain and Ireland to 1660. Edited by Joad Raymond. Oxford: Oxford University Press, pp. 1-14.

Raymond, Joad. 2011b. News. In The Oxford History of Popular Print Culture, Volume 1: Cheap Print in Britain and Ireland to 1660. Edited by Joad Raymond. Oxford: Oxford University Press, pp. 377-97.

Rech, Walter. 2019. Ambivalences of recognition: The position of the Barbary corsairs in early modern international law and international politics. In Piracy and Captivity in the Mediterranean 1550-1810. Edited by Mario Klarer. London: Routledge, pp. 76-98.

Robinson, Benedict S. 2007. Islam and Early Modern English Literature: The Politics of Romance from Spenser to Milton. Houndmills: Palgrave Macmillan.

Sisneros, Katie. 2016. "The Abhorred Name of Turk": Muslims and the Politics of Identity in Seventeenth-Century English Broadside Ballads. Ph.D. dissertation, University of Minnesota, Minneapolis, MI, USA.

Stein, Tristan M. 2012. The Mediterranean in the English Empire of Trade, 1660-1748. Ph.D. dissertation, Harvard University, Harvard, MA, USA.

Stein, Tristan. 2015. Passes and Protection in the Making of a British Mediterranean. Journal of British Studies 54: 602-31. [CrossRef]

Sutherland, James. 1986. The Restoration Newspaper and Its Development. Cambridge: Cambridge University Press.

Thomson, Ann. 1987. Barbary and Enlightenment: European Attitudes towards the Maghreb in the 18th Century. Leiden: Brill.

Tucker, Judith E. 2019. Piracy of the Eighteenth-Century Mediterranean: Navigating Laws and Legal Practices. In The Making of the Modern Mediterranean: Views from the South. Edited by Judith E. Tucker. Berkeley: University of California Press, pp. 123-48.

Vitkus, Daniel J. 1999. Early Modern Orientalism: Representations of Islam in Sixteenth- and Seventeenth-Century Europe. In Western Views of Islam in Medieval and Early Modern Europe: Perception of Other. Edited by David R. Blacks and Michael Frassetto. New York: St. Martin's Press, pp. 207-30.

Vitkus, Daniel. 2003. Turning Turk: English Theatre and the Multicultural Mediterranean, 1570-1630. Houndmills: Palgrave Macmillan.

Waite, Gary K. 2019. Jews and Muslims in Seventeenth-Century Discourse: From Religious Enemies to Allies and Friends. London: Routledge.

Williams, Keith. 1977. The English Newspaper. London: Springwood Books.

(C) 2019 by the author. Licensee MDPI, Basel, Switzerland. This article is an open access article distributed under the terms and conditions of the Creative Commons Attribution (CC BY) license (http://creativecommons.org/licenses/by/4.0/). 